University of South Florida

DIGITAL COMMONS

Digital Commons @ University of

@ UNIVERSITY OF SOUTH FLORIDA

South Florida

2012

\title{
Salinity Gradient Power (SGP): A Developmental Roadmap \\ Covering Existing Generation Technologies and Recent Investigative Results into the Feasibility of Bipolar Membrane- Based Salinity Gradient Power Generation
}

\author{
Clifford R. Merz \\ University of South Florida, cmerz@usf.edu \\ Wilfrido A. Moreno \\ University of South Florida,wmoreno@usf.edu \\ Marilyn Barger \\ Hillsborough Community College \\ Stephen M. Lipka \\ University of Kentucky
}

Follow this and additional works at: https://digitalcommons.usf.edu/msc_facpub

Part of the Electrical and Computer Engineering Commons, and the Life Sciences Commons

\section{Scholar Commons Citation}

Merz, Clifford R.; Moreno, Wilfrido A.; Barger, Marilyn; and Lipka, Stephen M., "Salinity Gradient Power (SGP): A Developmental Roadmap Covering Existing Generation Technologies and Recent Investigative Results into the Feasibility of Bipolar Membrane-Based Salinity Gradient Power Generation" (2012). Marine Science Faculty Publications. 549.

https://digitalcommons.usf.edu/msc_facpub/549

This Article is brought to you for free and open access by the College of Marine Science at Digital Commons @ University of South Florida. It has been accepted for inclusion in Marine Science Faculty Publications by an authorized administrator of Digital Commons @ University of South Florida. For more information, please contact digitalcommons@usf.edu. 


\title{
SALINITY GRADIENT POWER (SGP): A DEVELOPMENTAL ROADMAP COVERING EXISTING GENERATION TECHNOLOGIES AND RECENT INVESTIGATIVE RESULTS INTO THE FEASIBILITY OF BIPOLAR MEMBRANE-BASED SALINITY GRADIENT POWER GENERATION
}

\author{
Clifford R. Merz, ${ }^{*}$ Wilfrido A. Moreno,† Marilyn Barger, $\ddagger$ and Stephen M. Lipka \\ *College of Marine Science, University of South Florida, St. Petersburg, FL, USA \\ $†$ College of Engineering, University of South Florida, Tampa, FL, USA \\ \$Florida Advanced Technological Education (Flate) Center for Excellence, \\ Hillsborough Community College, Tampa, FL, USA \\ $\S U K$ Center for Applied Energy, University of Kentucky, Lexington, KY, USA
}

\begin{abstract}
Besides wind and solar-based renewable energy technologies, marine sources are being actively discussed. Sources of marine renewable energy traditionally have included ocean currents, ocean waves, tides, thermal gradients, and salinity gradients. Salinity gradient power (SGP) is an attractive marine renewable resource because it possesses not only the largest energy potential but likely the largest total available resource as well. SGP is instantly available when diluted and concentrated ionic solutions are mixed; is renewable, sustainable, and produces no $\mathrm{CO}_{2}$ emissions or other significant effluents that may interfere with global climate. The ultimate challenge is in the economics of the recovery method used and the matching of the resulting energy density delivered to a suitable end application. The transformative technical challenges required in advancing the knowledge and understanding of SGP, both within and across related scientific fields, lies in advances in membrane development, supply source utilization, energy generation, and storage/delivery of the generated power. This article begins with an introductory overview of SGP, provides background into the major SGP membrane-based processes under development, and then discusses recent investigative results into the use of bipolar membranes in SGP generation applications.
\end{abstract}

Key words: Salinity gradient power (SGP); Dialytic battery; Osmotic power generation; Bipolar semipermeable membrane; Reverse electrodialysis (RED); Ocean energy

\section{SALINITY GRADIENT POWER (SGP) INTRODUCTION AND OVERVIEW}

Besides wind and solar-based renewable energy technologies, marine sources are being actively discussed. Sources of marine renewable energy traditionally have included ocean currents, ocean waves, tides, thermal gradients, and salinity gradients. Power estimates of these five marine sources are presented in Table 1 in terms of their maximum power and energy potential expressed as hydraulic water head (17,56). As presented in Table 1, the worldwide salinity gradient ocean/river resource is estimated at 2.6 TW.

SGP is an attractive marine renewable resource because it possesses not only the largest energy potential but likely the largest total available resource as well. As a point of reference, in 2008 
Table 1. Marine Renewable Resources

\begin{tabular}{lcc}
\hline Resource & $\begin{array}{c}\text { Power } \\
\text { (terawatts, TW) }\end{array}$ & $\begin{array}{c}\text { Energy } \\
\text { Potential (m) }\end{array}$ \\
\hline Currents & 0.05 & 0.05 \\
Waves & 2.7 & 1.5 \\
Tides & 0.03 & 10 \\
Thermal gradient & 2.0 & 210 \\
Salinity gradient & 2.6 & 240 \\
\hline
\end{tabular}

the world's energy consumption was estimated at 16.9 TW with net electrical generation at $2.2 \mathrm{TW}$ (6). Considering the vastness of the potential resources available, even inefficient extraction could be acceptable as long as there is an adequate return on investment.

Recognition of salinity gradients as a potential energy generation source can be traced back at least to the discussion of electrolyte diffusion through charged membranes by Teorell (52) in 1935 and Meyer and Silvers (32) in 1936. If "fresh" (e.g., river or brackish water sources) and "salty" (i.e., seawater or highly saline brines) waters are mixed randomly together, their physicochemical potentials will quickly reach an equilibrium without any practical chance of capturing the sizable amount of the released energy. However, if this mixing is done in a controlled fashion, then the free energy release can be available for further conversion into useable energy. This is the basic premise for SGP generation.

SGP, sometimes referred to as Blue Energy in the more recent literature, produces no climatealtering emissions, requires little or no fuel costs, and the salts are not consumed in the process. Unlike wind or solar, SGP is nonperiodic, renewable, and sustainable via the earth's continuous evaporation/precipitation hydrologic cycle. This naturally occurring instant energy source exists at the interface between waters of differing salinities and is particularly concentrated where rivers flow into the ocean or locations of subterranean brines and salt deposits. In fact, it was suggested by Wick and Isaacs (57) in 1978 that more energy could actually be extracted from salt deposits of many oil-containing "salt domes" than from the oil itself.

Recognizing SGP's large and untapped natural resource has led to significant interest over the last
60 years. Besides the naturally occurring ocean/ river salinity gradient sources initially considered, the environmentally safe disposal of anthropogenic-derived sources such as agricultural drainage water and highly saline industrial/desalination waste brines present a significant and increasing source of additional recoverable renewable energy $(5,7,8,11,14,16,21,24,27,28,30,31,34-36,38,41,55)$. As an example, to meet growing drinking water needs the use of desalination is increasing globally. However, coupled with the benefits of fresh water production are the challenges of managing the concentrated waste stream produced. As a growing practice, drinking water desalination plants and wastewater treatment facilities are frequently being collocated near power generation stations. The application of SGP processing to the concentrated waste stream offers not only an additional management option but also provides the opportunity for efficient economic on-site energy recovery and ongrid customer energy delivery.

The ultimate challenge was and still is in the economics of the recovery method used and the matching of the delivered energy density to a suitable end application. The transformative technical challenges required in advancing the knowledge and understanding of SGP, both within and across related scientific fields, lies in advances in membrane development, supply source utilization, energy generation, and storage/delivery of the generated power. This article begins with an introductory overview of SGP, provides background into the major SGP membrane-based processes under development, and then discusses recently completed investigations and evaluations into the suitability and possible SGP uses of bipolar membranes (BPM) in these processes $(30,31)$ and SGP in general.

\section{EXISTING SGP MEMBRANE PROCESSES DISCUSSION}

Although numerous SGP solutions have been discussed in the literature, the most often cited technologies focus on variations of two existing water desalting membrane processes, reverse osmosis (RO) and electrodialysis (ED), where a significant driving force in the industrial development of membranes already exists. The first SGP 
approach utilizes the phenomena of chemical potential equalization via differential osmotic pressure differences across nonionic membranes [pressure retarded osmosis (PRO)] and the second utilizes the electrochemical properties of solutions of differing saline concentrations (salinity) separated by charged semipermeable ion-exchange membranes [reverse electrodialysis (RED)]. Discussions of other SGP technologies, for example utilizing the vapor-pressure difference between two solutions of different concentrations at the same temperature (39), will be covered in a separate article.

\section{PRESSURE RETARDED OSMOSIS (PRO)}

\section{Basic Principles: Osmosis and Osmotic Power Concepts}

Osmosis is a natural process of solvent (water) flow through a semipermeable membrane blocking the transport of salts (solute) dissolved in solution. The solvent flux is from the dilute to the concentrated solution and proportional to the osmotic pressure difference between the two solutions. This pressure difference occurs whenever a membrane separates a solvent from a solution and given almost entirely by the total concentrations of the dissolved species (ions or molecules), depending little on the individual species. The solutions are often electrolyte solutions, such as $\mathrm{NaCl}$ in water, of differing concentrations.

As an example, a river flowing into the sea carries with it a physical-chemical potential energy in its low salt content. This "osmotic salinity potential" can be calculated using the van't Hoff equation (equation 1) for osmotic pressure $\left(\Pi_{\text {osmotic }}\right)$ where $R$ is the universal gas constant, $T$ the absolute temperature, and $C$ the $\mathrm{NaCl}$ concentration difference between the two solutions:

$$
\Pi_{\text {osmotic }}=2 * C_{\mathrm{NaCl}} R T
$$

Using equation 1 , the equivalent osmotic pressure head between typically $35 \mathrm{ppt}$ seawater $(0.52$ $\mathrm{M} \mathrm{NaCl}$ ) and fresh water is computed to be about 24 atm; equivalent to a $240-\mathrm{m}$ waterfall at the mouth of every river (Table 1). This large source of energy occurs unnoticed, however, since the solubility of $\mathrm{NaCl}$ is almost independent of temperature and, in accordance with Le Chatelier's principle, has a very small heat of dilution.

The first description of a concept to utilize the osmotic pressure of seawater as a source of energy was given by Norman (35) in 1974. Two patents on energy generation by osmosis were filed independently by Jellinek (15) and Loeb (26) in 1974. In 1975 Loeb (27) made a first economic analysis of this process and proposed the term "pressure retarded osmosis (PRO)." Norman showed that the maximum (reversible) work obtained when $1 \mathrm{~m}^{3}$ of fresh water per second is brought in contact with seawater is approximately $2.2 \mathrm{MW}$, some of which should be recoverable. Large rivers have flows of $10,000 \mathrm{~m}^{3} / \mathrm{s}$ or more; this illustrates the large potential of osmotic power, even if only a small fraction of the theoretical energy can be transformed into electrical power.

The data presented in Table 1 covers ocean/river salinity gradients only. Not included are the energy potential available from hypersaline lakes (e.g., the Great Salt Lake or Dead Sea), salt pans adjacent to the ocean, and subterranean and submarine salt deposits, which could increase Table 1 SGP's estimated power potential by at least a factor of two (58). Further additions of the previously mentioned anthropogenic-derived "salty" sources such as agricultural drainage water and highly saline industrial/desalination waste brines will only further increase the estimated power potential and provide additional renewable and sustainable energy resources to help offset our near single focus on fossil fuel related sources.

\section{Basic Principles: PRO Operation Discussion}

One way to begin the discussion of PRO SGP is by first reviewing the basic operational characteristics of RO and then highlighting the similarities and differences between RO and PRO. Basic RO operation consists of pressurizing the concentrated ocean/brackish water input stream to a point much above $\Pi_{\text {osmotic }}$, such that freshwater (solvent) contained within the concentrated solution is forced through a nonionic membrane and into a collection vessel. It is this counter pressurization that leads to the term "reverse osmosis," with the resulting effect being an even higher concentrated solution. 
Basic PRO SGP operation begins with solutions of differing salinities (or as often presented: seawater and freshwater) being brought into contact via a nonionic membrane. Through naturally occurring $\Pi_{\text {osmotic }}$-driven direct osmosis, freshwater is forced through the membrane into the concentrated solution, resulting in a less concentrated/more brackish water solution.

It is this direct osmosis-driven water flux transport that is critical to PRO. As in RO, the more brackish/less concentrated solution is pressurized but now to a level much lower than $\Pi_{\text {osmotic }}$. This is because as the applied hydraulic pressure approaches $\Pi_{\text {osmotic, }}$ the water flux through the membrane decreases. Optimum PRO hydraulic pressure for the concentrated solution is approximately $\Pi_{\text {osmotic }} / 2$, at which the direct osmotic-driven solvent transport will be partially reduced or retarded (42), thus the term "pressure retarded osmosis." At $\Pi_{\text {osmotic }} / 2$, approximately half of the theoretical energy can be transferred to electrical power, or about $1 \mathrm{MW} / \mathrm{m}^{3} / \mathrm{s}$ of fresh water.

The water flux transport of low-pressure freshwater into the high-pressure concentrate results in the pressurization of the entire volume of brackish water output (43). Thus, the osmotic process increases the volumetric flow of the high-pressure solution and is the key energy transfer mechanism (10) with the gross energy gain per unit membrane area equal to the product of the pressure difference multiplied by the volume flow of fresh water through the membrane. As shown in Figure 1, PRO SGP generation conceptual process flow sheet, the resulting brackish water output from the membrane module is split into two flows-one is depressurized through a hydropower turbine to generate power and the other passes through a pressure exchanger to pressurize the seawater feed $(42,48)$.

\section{Current and Future State of PRO}

Key to PRO is the cost-effective manufacture of semipermeable membranes with high water flux permeability and high salt retention (low salt flux). Current PRO spiral wound or hollow fiber nonionic membranes are primarily made from cellulose acetate (CA) and polyamide (PA) in the form of thin film composites (TFC) prepared by interfacial polymerization. According to the European Commission (EC) salinity power estimates, the first commercial 10 MW PRO SGP generation plants would need membranes capable of production of at least $6 \mathrm{~W} / \mathrm{m}^{2}$, corresponding to approximately $1,700,000 \mathrm{~m}^{2}$ of membrane (13). Membrane performance has improved over the last 30 years from initial reported power densities of $<0.1 \mathrm{~W} / \mathrm{m}^{2}$ for then commercially designed RO membranes to values of $3.7 \mathrm{~W} / \mathrm{m}^{2}$ with specifically designed prototype TFC PRO SGP membranes (4).

Research into industrial-scale PRO membrane performance improvement and production at reduced cost continues. As an example, the Norwegian utility company, Statkraft (www.statkraft.com) began SGP research in 1997 together with the Norwegian Foundation for Scientific and Industrial Research (SINTEF). In 2003 Startkraft opened the first laboratory dedicated to SGP with a focus on highperformance membranes for PRO and opened the world's first prototype facility $(10 \mathrm{~kW}$ design capacity) for PRO SGP in 2009. Through partnering agreements with groups such as GKSS Forschungszentrum in 2001 (42) and Nitto Denko/ Hydranautics in 2011 (49), Statkraft continues to advance the research, development, and supply of PRO SGP membranes and PRO SGP energy facility generation technologies.

\section{REVERSE ELECTRODIALYSIS (RED)}

\section{Basic Principles: Electrodialysis (ED) General Discussion}

One way to begin the discussion of RED SGP is by first reviewing the basic operational characteristics of electrodialysis (ED). ED is a commonly used electromembrane process for drinking water desalination and concentrating of aqueous solutions. ED is different from other desalination membrane processes, such as RO, in that it is electrically driven rather than pressure driven with only charged ions and associated water transferred (electro-osmosis). ED depends on the following general principles:

1. Six major ions make up $>99 \%$ of the salts dissolved in seawater: four cations [sodium $\left(\mathrm{Na}^{+}\right)$, magnesium $\left(\mathrm{Mg}^{2+}\right)$, calcium $\left(\mathrm{Ca}^{2+}\right)$, and potassium $\left(\mathrm{K}^{+}\right)$] and two anions [chloride $\left(\mathrm{Cl}^{-}\right)$and sulphate $\left.\left(\mathrm{SO}_{4}{ }^{2-}\right)\right]$. 


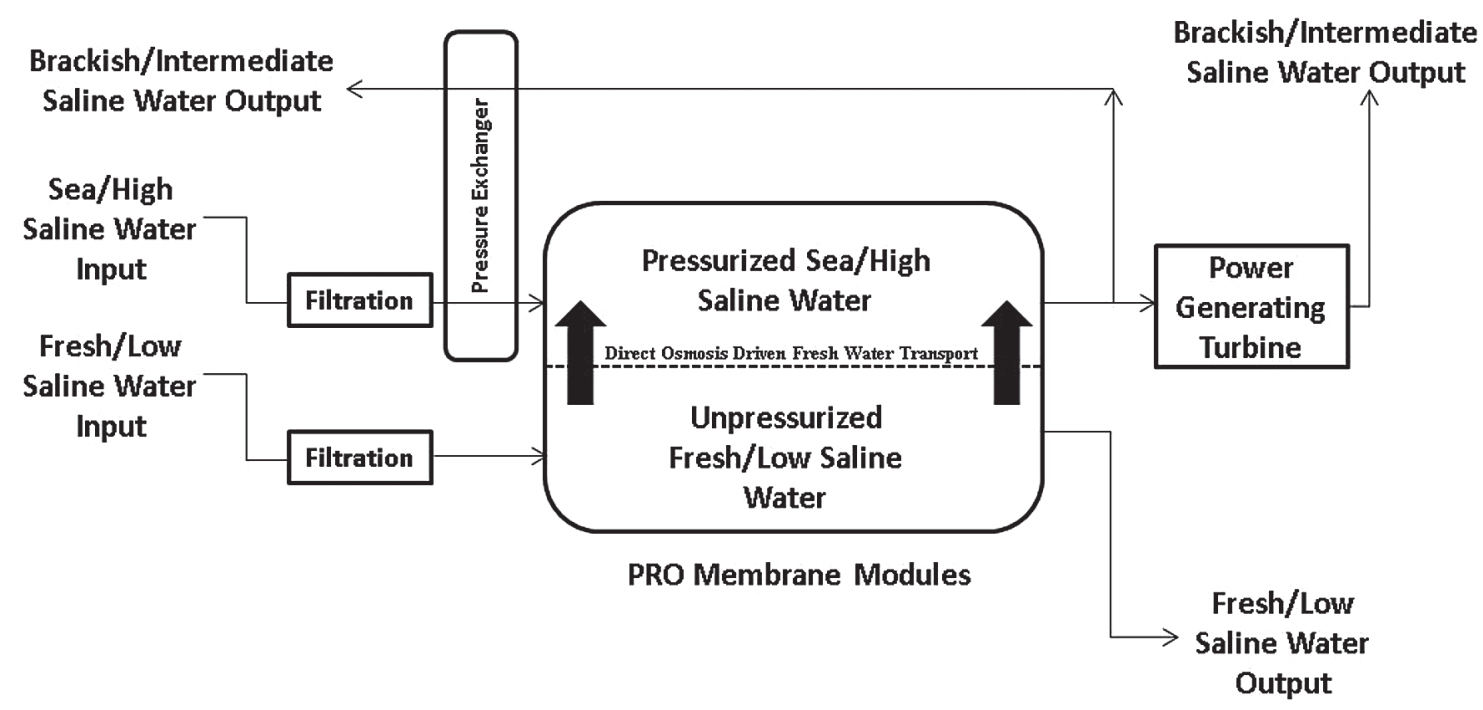

Figure 1. PRO SGP generation conceptual process flow sheet (48).

2. These ions are attracted to electrodes with an opposite charge.

3. Seawater is nominally $86 \%$ sodium chloride $(\mathrm{NaCl})$ with $\mathrm{Na}^{+}$and $\mathrm{Cl}^{-}$almost completely dissociated.

When $\mathrm{NaCl}$ is dissolved in water, it is ionized and dissociates into hydrated $\mathrm{Na}^{+}(\mathrm{aq})$ cations and $\mathrm{Cl}^{-}$ (aq) anions. "Free ions" such as $\mathrm{Na}^{+}(\mathrm{aq})$ and $\mathrm{Cl}^{-}$ (aq) are so well hydrated that they are too far apart to interact directly with each other, even in solutions of great ionic strength (25). Because $\mathrm{Na}^{+}$(aq) and $\mathrm{Cl}^{-}$(aq) are so well hydrated in solution, sodium chloride in water does not diffuse as a single molecule; instead the sodium ions and chloride ions move freely through the electrolyte solution (33).

Figure 2 illustrates a typical ED unit layout. Anion exchange membranes (AEM) and cation exchange membranes (CEM) are alternately arranged to form a repeating unit called a "cell." The basic ED stack consists of several hundred AEM/CEM cell pairs bound together between end electrodes (anode and cathode). Cations, under the influence of the negative electrode, move through the CEM but are stopped at the AEM interface. Similarly, anions under the influence of the positive electrode move through the AEM but are stopped at the CEM interface. By this arrangement, concentrate (the solution receiving the ions) and desalination (the solution being depleted of ions) streams are created in the pathways between the alternating membrane pairs.

Besides being used for drinking water production, ED stack configurations have been modified to target certain specific tasks through addition of differing membrane types and/or arrangements. Two such examples include:

1. Inclusion of BPMs in conjunction with conventional AEMs and CEMs to convert salts in solution into their corresponding acids $(\mathrm{HCl})$ and bases $(\mathrm{NaOH})$ by a process called electrodialytic splitting (29).

2. Electrodialysis metathesis (EDM), an ED variation that uses two AEM/CEM cell pairs as the repeating unit instead of one to produce a desalinated water stream, two highly soluble concentrate streams, and one electrolyte stream. EDM was recently investigated with respect to zero liquid discharge desalination of brackish water (3).

\section{Basic Principles: Electric Field, Current Passage, and Ion-Exchange}

An electric field in an electrolyte solution produces transference of ionic species in the direction of the current that is proportional to the gradient of the electric field and the electrochemical valence of the ionic species. It is irrelevant whether the field is 

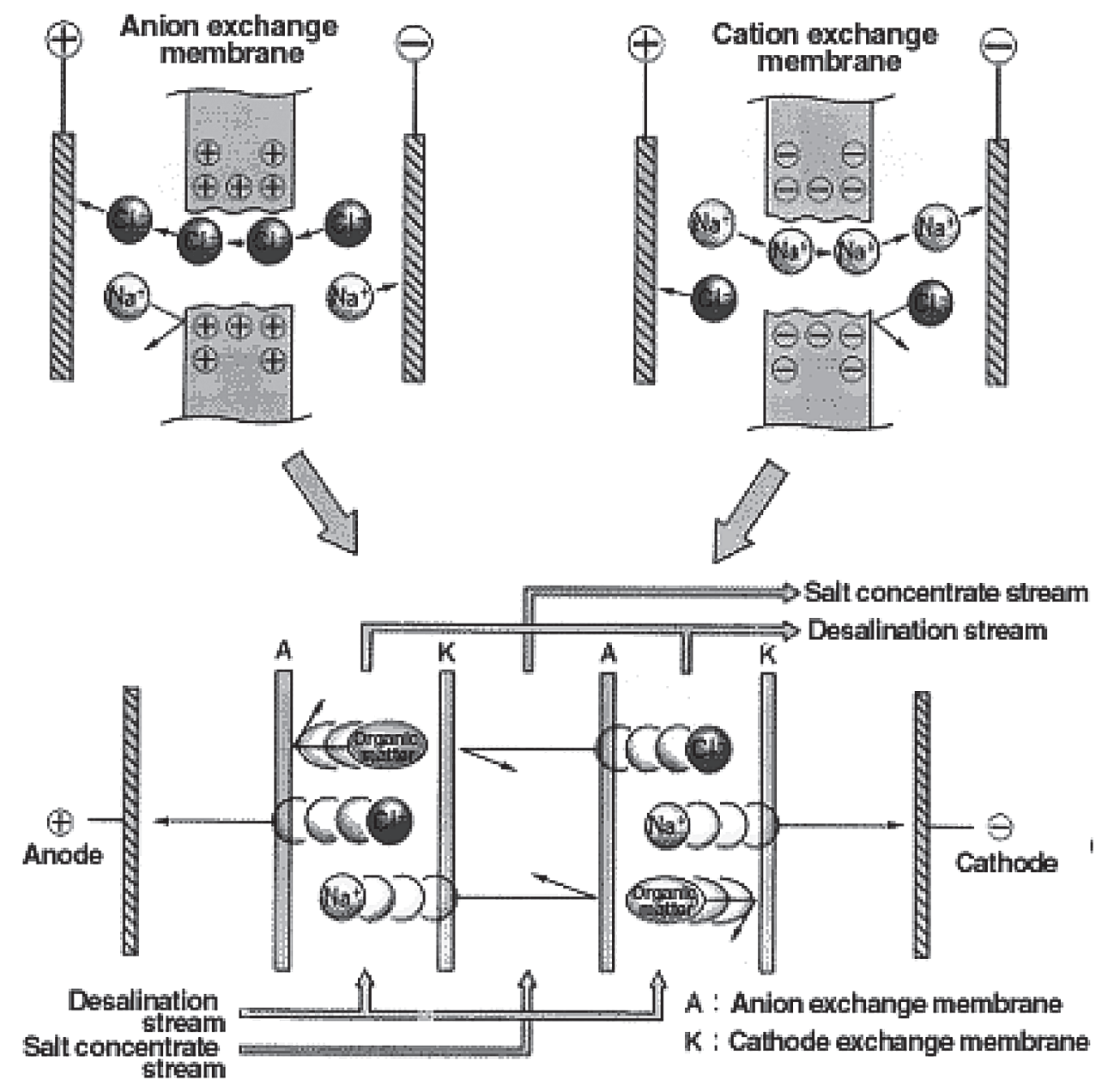

Figure 2. Typical electrodialysis (ED) unit layout (source unknown).

generated by an external source (as in ED) or internally generated via concentration gradient driven diffusion (as in a RED concentration cell), since the individual ions have no means of knowing the origin of the electric field (12).

If an ion-exchange membrane is in contact with an ionic solution, a distribution of ions in the solution will be established as well as a distribution inside the membrane (Donnan equilibrium). If the membrane has a negative fixed charge, ions of opposite charge (positively charged ions or counter-ions) will be attracted towards the membrane surface while ions of the same charge (negatively charged ions or co-ions) are repelled from the membrane surface. Ions with the same charge as the fixed ions (co-ions) are excluded and cannot pass through the membrane. This effect is known as the Donnan exclusion. Because of the fixed charge, there will be an excess of counter-ion charge at the interface and a so-called electrical double layer (EDL) is formed.

Electric current in an ion-exchange membrane transfers predominantly via counter-ions by diffusion. The relationship between the maximum reversible open circuit voltage (OCV) membrane potential $\left(\mathrm{E}_{\mathrm{rev}}\right)$ and the standard-state Gibbs free energy is often discussed based on an extension of the NernstPlanck equation for monopolar charged membranes, presented in equation 2 .

$$
\mathrm{E}_{\mathrm{rev}}=\mathrm{E}_{\text {cell }}-(\mathrm{RT} / n \mathrm{~F}) \ln \left(\mathrm{a}_{ \pm} \mathrm{conc} / \mathrm{a}_{ \pm} \mathrm{dil}\right)^{v}
$$

Specific equation 2 details include using: an ideal permselective membrane as a salt bridge, a 1, 1 valence electrolyte, carefully selected end electrode pairs of identical composition such that the EMF of the galvanic cell $\mathrm{E}_{\text {cell }}=\mathrm{E}_{\text {Cathode }}^{\circ}-\mathrm{E}_{\text {Anode }}^{\circ}=0.00$ 
VDC, $\mathrm{a}_{ \pm}=$ionic activities (approx. concentrations), $n$ is the number of electrons transferred, and $v=$ charge on the active ion. Using equation 2 and considering an ideal membrane $(\mathrm{a}=1.0)$, monovalent active ions such as $\mathrm{Na}^{+}$(aq) and $\mathrm{Cl}^{-}$(aq), and a 1:10 activity ratio for the two solutions (i.e., concentrated solution $=10 *$ dilute), $\mathrm{E}_{\text {rev }} \mathrm{OCV}$ is:

$$
\begin{aligned}
& \mathrm{E}_{\mathrm{rev}}=0.0-\left[\mathrm { v } ^ { * } \left(8.314 \mathrm{~J} \mathrm{~K}^{-1} \mathrm{~mol}^{-1 * 298 \mathrm{~K}) / 1 * 96,500}\right.\right. \\
& \left.\mathrm{C} \mathrm{mol}^{-1}\right] \ln (0.1)
\end{aligned}
$$

$\mathrm{E}_{\mathrm{rev}}$ may be higher if the co-ion is more mobile than the counter-ion and if there is little Donnan exclusion of the co-ion. As an example, Ohya (38) reported on a single AEM/CEM test pair separated by a center region and reported maximum cell OCV $\mathrm{E}_{\text {rev }}$ values of nominally $0.100 \mathrm{~V}$ after several hours before dropping off.

However, under load the voltage across the load depends upon the internal resistance and current drain $(30,37)$. It has been shown that a permselective ion-exchange membrane may be regarded as a resistor and a capacitor in parallel (22). Consequently, the condition of preservation of macroscopic electroneutrality, which underlies the basic Nernst-Planck equation for the diffusive flow of charged species, does not apply to the individual compartments of a concentration cell separated by a permselective, charged membrane. Thus, a net excess of anions and cations, respectively, may be generated at the two membrane interfaces. The local perturbations in the electron neutrality will induce a passage of electric current when electron transfers to the electrodes (14).

\section{Basic Principles: Reverse Electrodialysis (RED) General Discussion}

ED units have pathways, separated by a CEM/ AEM cell pairs, where externally supplied direct current provides the motive force for ion migration from the low concentration side to the higher concentration side. Because concentration gradient-driven systems force ion migration from the high concentration side to the low, these systems are frequently referred to as reverse electrodialysis (RED) or dialytic batteries. RED systems can be operated in fuel cell-like configuration (an electrochemical concentration cell in which the chemical energy in a fuel is converted directly into electrical energy) or a battery depending upon if the source of the energy is continually fed to the cell or internally stored and consumed (18).

In RED, the driving force is provided solely by the salinity concentration gradient. Because of the difference between the chemical potentials of the salt ions in the brine and the dilute solutions, there will be voltages across each membrane and the back EMF of the transmembrane voltages are additive. The solution, membranes, and other irreversibilities, such as diffusion potentials in the solutions, contribute to an internal electrical impedance of the dialytic battery. Useful power is obtained via leads connected to the end electrodes across an electrical load. Peak power will be delivered to the external load when the load impedance equals the conjugate of the internal impedance of the battery (21).

RED provides a route for direct conversion of free energy of mixing into electrical power. Detailed theories of monopolar membrane potentials, linked to the fundamental studies of Nernst, Planck, and Ostwald, have been developed in the past $(12,19,32$, 46,52). As early as 1952 Manecke (28) experimented with an array of three membranes in a form that resembled the RED process and Pattle $(40,41)$ constructed a similar membrane stack and obtained $0.015 \mathrm{~W}$ from it by operating at an elevated temperature. In 1976 Weinstein and Leitz (54) converted an ED stack into a dialytic battery by changing the external circuit and operating conditions. The optimum power, $0.235 \mathrm{~W}$ or $0.33 \mathrm{~W} / \mathrm{m}^{2} /$ pair, was obtained with $30 \mathrm{AEM} / \mathrm{CEM}$ pairs with an effective area of $232 \mathrm{~cm}^{2}$ and with the concentration of dilute and concentrated solution, $0.026 \mathrm{M}$ (river water) and $0.57 \mathrm{M}$ (seawater), respectively.

In ED applications, the solution compartments and membranes, being in series, must carry the same electrical current. In the solution compartments, both the cations and anions carry the current. In the membranes, however, only one type of ion (cation or anion) can do this. Therefore, the ions in the membranes must travel at twice the speed that they move in the bulk solution compartments. This causes the concentration of the ions to be depleted on the entrance side of the membrane in comparison with the concentration in the bulk solution. This concentration polarization requires a higher current to transport the ions. If the current is increased to the point where the membrane surface on the entrance side is 
totally depleted of ions ( $\left.\mathrm{i}_{\mathrm{lim}}\right)$, there will be an increase in the resistance and a corresponding boost in energy consumption.

However, in purely diffusive driven systems such as RED concentration cells, preferential ion transport occurs through the membrane according to the internally generated concentration gradient driven driving force. With the concentration of solute at the membrane surface dependent upon the flux through the membrane, membrane retention, the diffusion coefficient of the solute $\mathrm{D}$, and the thickness of the concentration boundary layer d (i.e., the region near the membrane in which the concentration of solute varies). Because of current densities generally below $\mathrm{i}_{\text {lim }}$, low transport rates, and low solute mass transfer rates, it is frequently assumed that the resistance to ion transport in concentration cell systems is determined primarily by the membrane phase with boundary layer resistances neglected (47).

\section{Current and Future State of RED}

Key to RED is the cost-effective manufacture of semipermeable ion-exchange membranes with low electrical resistance (the permeability for the counterions under an electrical load potential gradient should be high to minimize membrane IR drop loss) and high permselectivity (should be highly permeable for counter-ions but should be impermeable to co-ions, nonionized molecules, and solvents). Current CEMs are typically made of a cross-linked base polymer containing electronegative fixed charge sulfonate $\left[-\mathrm{SO}_{3}{ }^{-}\right]$or carboxylate groups $\left[-\mathrm{COO}^{-}\right]$attached to the polymer. AEMs are typically made of a cross-linked base polymer containing electropositive fixed charge quaternary ammonium groups $\left[-\mathrm{N}(\mathrm{CH})_{3}{ }^{+}\right]$. Each AEM/CEM polyelectrolyte has a network of molecular-size pores that although generally too small to allow significant water flow (44) does none the less allow for some level of water flux transport.

For electrical neutrality to be maintained, each of the fixed charges on the membrane must be associated with an ion of the opposite charge. The ion can easily move from one fixed charge to another. Thus, the membrane can pass an electrical current in the form of migrating ions. Since the fixed-charged groups on the membrane repel likecharged ions, cations cannot enter the anion exchange membrane (1). Not being perfectively semipermeable, the membranes do not completely reject ions of the same charge; however, their permselectivity between counter- and co-ions can reach values up to $99 \%$ (18). The permselectivity decreases with increasing ion concentration of the outside solution and decreasing degree of cross linking of the ionexchange membrane.

Research into industrial-scale RED membrane performance improvement and production at reduced cost continues. As an example, a Dutch consortium called company REDstack (www.red stack.nl) was formed in 2005 to develop the technology needed to build a RED power plant. REDStack and partners Westus, KEMA, and others are collaborating to develop low-cost RED monopolar ion-exchange membranes and commercialize RED technologies. A REDstack RED pilot installation facility has been operational at Frisia Zoutfabrieken in Harlingen since 2009 (45).

\section{APPLICABILITY OF BPMs IN SGP APPLICATIONS}

\section{BPM Use Discussion}

Detailed evaluation of PRO and RED systems revealed differing membrane types and approaches under development. Prior investigations suggest that with highly saline brine as the concentrated solution, the gain for RED may not be as great as that for PRO because the voltage increases only as the logarithm of the concentration ratio whereas RED seems to be more attractive for power generation using ocean and river water $(43,58)$. It is evident that there is a need for a simplified electric current generating system that does not suffer from the complexities of the dual membrane systems (RED), especially when a plurality of cells are used in tandem, while allowing for direct osmosis driven water flux transport (PRO). If such a membrane could be found, it could significantly advance SGP generation capability.

An extensive literature and membrane evaluation review revealed the presence of BPMs and their similarity to a fuel cell membrane electrode assembly (MEA) (23). A BPM consists of a monopolar CEM and monopolar AEM joined together with an intermediate transitional phase layer in between. 
Although made up of well-defined components, once combined, the BPM acquires some unique capabilities and additional uses. These include:

1. An apparent variation in membrane potential depending upon which side is in contact with the more concentrated solution, which is not the case in monopolar ion-exchange membranes (51).

2. Its use in converting water-soluble salts to their corresponding acids and bases via the process of water dissociation (electrodialytic splitting), where $\mathrm{H}^{+}$and $\mathrm{OH}^{-}$ions are removed from the transitional phase layer and replenished by water transported into the membrane (2).

The ion-transport properties of BPM are quite different from those of monopolar ion-exchange membranes. To explain the transport of ions through a charged membrane, the interaction between ions and fixed charge groups inside the membrane as well as at the interface has to be considered. In BPMs, there are three interfaces:

1. The interface between the concentrated saline solution and the BPM.

2. The interface between the anion-exchange membrane and the cation-exchange membrane (intermediate transitional phase layer).

3. The interface between the BPM and the dilute saline solution.

When an electric field is established across a BPM, the anions and cations contained in the intermediate layer migrate through the AEM and CEM in the direction of the electric field. Because of the current flow the intermediate layer becomes impoverished in salt and its resistance increases. Two EDL and Donnan potential differences develop between the intermediate and outside layers and are opposite to the applied field.

\section{BPM Side Orientation}

The two-monopolar layers of a BPM always differ in their fixed ion molarities and in the sign of their charge. These differences are the cause of the asymmetrical character of BPMs (20). Unlike monopolar ion-exchange membranes (12), the BPM facing direction and intermediate phase condition will alter the direction of the membrane potential charge. The intermediate layer in a BPM seems to act as an alteration barrier for the membrane potential according to the membrane facing direction (50). If the concentration of the immediate layer is lower than that of the external solutions, the ion-exchange layer that faces the concentrated solution will play the dominant role in determining the whole membrane potential, because the concentration ratio between the intermediate layer and the external concentrated solution is much higher than that between the intermediate phase and the external dilute solution.

According to evolving literature convention, a BPM is in the (+) orientation when the denser, positively charged (anion-active) AEM layer is in contact with the more concentrated solution. Generally, the values of the concentration polarization $\mathrm{E}_{\mathrm{c}}$, consisting of two Donnan potentials on the twoboundary membrane solution, are less positive with BPMs in the $(+)$ orientation than the $(-)$ orientation, thus leading to an increased cell output membrane potential voltage (20).

\section{BPMs and Their Uses}

The unique characteristics of BPMs coupled with the MEA similarity lead to questioning whether BPMs may also possess unique characteristics when used in an electrochemical concentration fuel cell. It was realized initially that if $100 \%$ AEM/CEM permselectivity existed, that there would be no ion-transfer or water flux transport across the BPM. However, it was also realized that no perfect membrane exists and some transfer will occur, if only through the manufacturing defects present. The fundamental question centers on what the resulting water flux transport and delivered power density is and might be. Considering the vastness of the potential resource available, even inefficient extraction could be acceptable as long as there is an adequate return on investment and a suitable end application identified.

\section{BPM-BASED SGP RESEARCH TEST RESULTS}

\section{Research Objectives}

The overarching goal was to provide both a contribution to the body of knowledge as well as to 
suggest a possible solution path to the engineering problem of extraction of useful energy from available dilute and concentrated saline solutions. Pursuant to this, an investigation was conducted to determine the feasibility of BPM-based salinity gradient power generation.

\section{Testing Summary}

The testing effort consisted of an extended testing/monitoring program designed to determine OCV and loaded voltage and current output vice parameters including: 1) external electrical loading; 2) solution concentration; 3) membrane orientation; 4) scalability; 5) water flux transport.

Synthetic seawater solutions were used to minimize membrane and electrode fouling effects. Inspection of the test fixtures, membrane, and electrodes was conducted during the testing period including the use of a scanning electron microscope (SEM) to ascertain membrane and electrode state of health. Detailed ion-transfer across the BPM was analyzed by $\mathrm{Cl}^{-}$ion titration of samples periodically removed from the test cells.

Electrochemical methods such as cyclic voltammetry (CV) and electrochemical impedance spectroscopy (EIS) along with equivalent circuit modeling were used to establish electrode processes and kinetics corresponding to changes in operating parameters. Statistical design of experiment (DoE) methods were used to investigate various parameter interactions. Cell performance testing consisted of various series/parallel test configurations using differing membrane cross sectional areas and external electrical loadings. Presented herein are specific details of the testing effort particularly relevant to SGP. These details include recent research findings as well as those discussed in the first author's dissertation (30).

\section{Specific Test Methodology and Details}

To examine BPM performance, specific test fixtures were constructed and operated for various periods of time and loading conditions with the results compared. The testing effort consisted of a monitoring program designed to determine OCV and loaded cell membrane potential voltage and current vice the following input parameters:
1. Standard atmospheric conditions.

2. Synthetic seawater solution temperature (5$40^{\circ} \mathrm{C}$, nominally).

3. Synthetic seawater solution concentration differences (e.g., 1:10, 1:100).

4. BPM end use differences (e.g., industrial electrochemical plating vs. water purification ED membranes).

5. Solution pumping speed (Fisher Scientific low flow peristaltic pump 13-876-1).

6. BPM side orientation.

7. Membrane scalability using baseline $1 \mathrm{X}, 0.34 \mathrm{X}$, and 3.54X test fixtures.

8. Silver (Ag) wire mesh electrodes.

Room temperature $\mathrm{CV}$ and EIS measurements were conducted over a frequency range of $10 \mathrm{MHz}$ to $1 \mathrm{mHz}$ using a Solartron SI 1260/1287 Frequency Response Analyzer and supporting test equipment to establish electrode, membrane, and full cell component characterization. Full cycle temperature and external electrical loading performance measurements were conducted using a using a data logger, computer, and supporting test equipment to establish cell membrane output potential characterization.

Close inspection of the test setup, membrane, and electrodes were conducted during the testing period. SEM and X-ray imaging techniques were used to ascertain membrane and electrode state of health. BPMs from several manufactures were obtained and used during the testing period for comparison. Specific membrane details came from the manufacturer and literature, as available, supplemented by testing.

Because of the number of cell components and their coupled parametric interactions, it was desirable to characterize each individually and determine their respective interactions using DoE analysis techniques via Statistical Analysis System's (SAS) statistical analysis package. EIS impedance plots and cell equivalent circuit modeling (ECM) was analyzed using Solartron's ZView2 software package by Scribner Associates, Inc.

\section{Synthetic Seawater Solution Discussion}

Instant Ocean ${ }^{\circledR}$ Synthetic Sea Salt, made by Aquarium Systems, was used throughout this testing effort to provide a suitable medium for a seawater concentration cell without the deleterious 
effects of marine biofouling. Test solutions along with nominal $\mathrm{Cl}^{-}$titration and $\mathrm{pH}$ measurement values were made as follows:

1. Highly saline concentrated brine test solution: 300 grams of Instant Ocean ${ }^{\circledR}$ added to enough deionized (DI) water $\left(18.2 \mathrm{MW}^{*} \mathrm{~cm}\right)$ to make $1 \mathrm{~L}$ of total solution; $\mathrm{pH}=8.1$ and $\mathrm{Cl}^{-}=3.62$ $\mathrm{M}(\mathrm{N})$.

2. 1:10 Test solution: $100 \mathrm{ml}$ of concentrated brine test solution added to $900 \mathrm{ml}$ of DI water; $\mathrm{pH}=$ 8.8 and $\mathrm{Cl}^{-}=0.45 \mathrm{M}(\mathrm{N})$.

3. 1:100 Test solution: $100 \mathrm{ml}$ of 1:10 test solution added to $900 \mathrm{ml}$ of DI water; $\mathrm{pH}=9.0$ and $\mathrm{Cl}^{-}=0.05 \mathrm{M}(\mathrm{N})$.

Although a 1:10 concentration difference exists between 1 to 2 and 2 to 3 , their molarities differed by $8: 1$ and $9: 1$, respectively, which concurs based on their respective activity coefficients and concentration values.

\section{Electrode Discussion}

In order to allow for the sole evaluation of the BPM in the seawater concentration test cell, the electrode material was carefully selected so as to only act as a charge collector. The chosen electrodes were made from standard silver $(\mathrm{Ag})$ wire mesh with a solid Ag tab soldered for good electrical conduction and increased clip test lead attachment longevity. Initial surface cleaning included a 20-min dip in $3 \mathrm{M} \mathrm{HCl}$ followed by a DI water rinse. Electrode overall cross section is 7.6 by 7.6 $\mathrm{cm}$ with 7 by $7 \mathrm{~cm}$ in solution contact. SEM analysis along with electrochemical-, physical-, and performance-based testing of the Ag mesh electrode confirmed that corrosion effects were found not to be a contributor to the overall cell potential, confirming that they functioned simply as charge collectors and allowing for the independent performance evaluation of the BPM.

\section{BPM Discussion}

Membrane Details. BPMs from two manufactures were used in the testing effort. Details specific to each membrane are provided as follows:
1. Membranes International Inc., USA (MII BPM9000): a) Primarily an industrial grade membrane used in the metal plating industry; b) Polymer structure-gel polystyrene crosslinked with divinylbenzene; c) Thick, stiff, "fabric-like appearance"; d) Shipped dry in "open" container; 5) CEM: surface rough and dark color; functional group-sulphonic acid; e) AEM: Surface rough and light color; functional group-quaternary ammonium; f) Selected test cell measured and vendor provided sample properties: water uptake $=14.4 \%$; electrical resistance $<1$ Ohm (EIS measured).

2. Fumatech, Germany (Fumasep ${ }^{\circledR}$ FBM): a) Primarily used in the water purification industry; b) Polymer structure-\{Kraton, PPO [poly (phenyleneoxide)]\} cross-linked with PEEK [Poly(etheretherketone)]; c) Thin, flexible, "sandwich wrap like appearance"; d) Shipped in sealed container surrounded by $1 \mathrm{M} \mathrm{NaCl}$ solution; e) CEM: surface smooth and shinny; functional group-sulphonic acid; d) AEM: surface not slippery and opaque; functional groupamines; e) Selected test cell measured and vendor provided sample properties: water uptake $=$ $15.3 \%$; electrical resistance $<3 \mathrm{Ohm}$.

SEM Test Results and Summary. SEM images of new and used BPMs were made at various times during the testing program. Figures 3 and 4 present typical examples showing possible solution pathways.

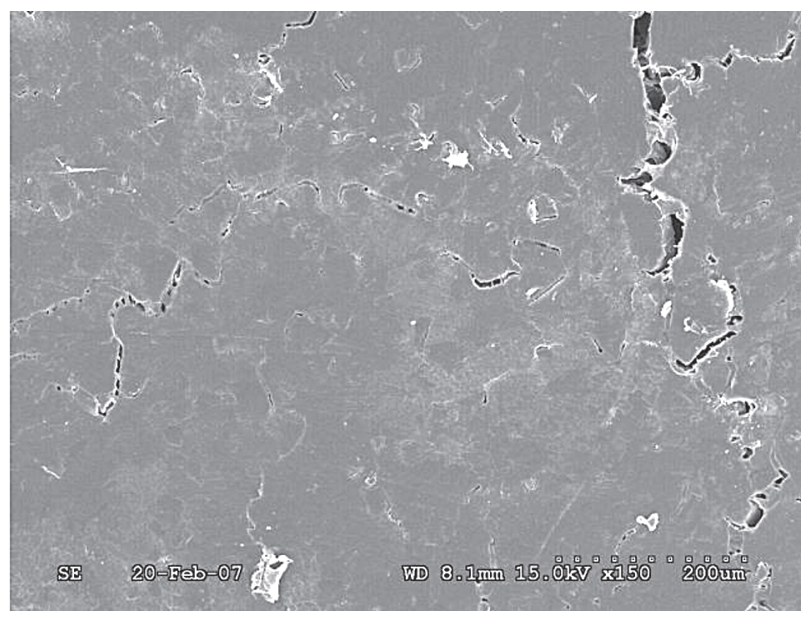

Figure 3. Typical “new' AEM SEM image. 


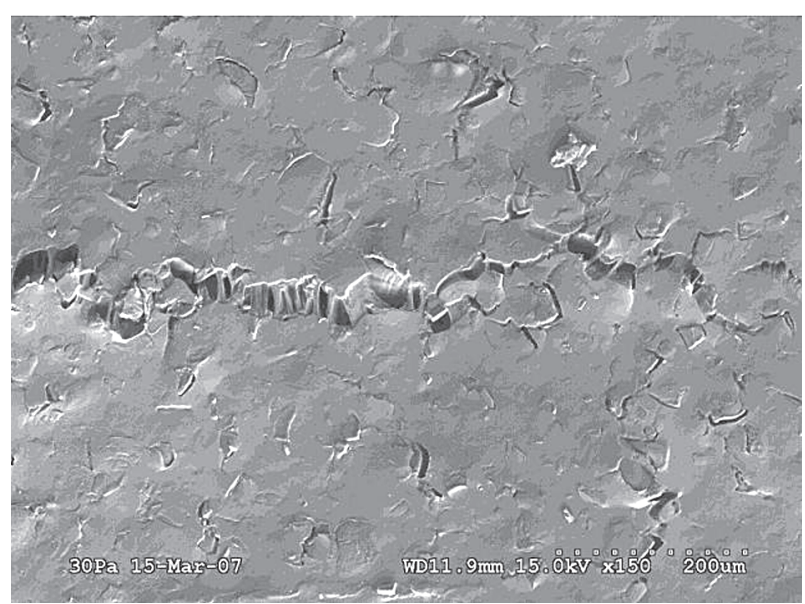

Figure 4. Typical "used” AEM SEM image.

Analysis of SEM images revealed:

1. The presence of many small holes distributed unevenly on the membrane surface.

2. The hole size sometimes is much smaller than the distance between discrete holes and sometimes much larger causing trench like lines.

3. Additional "openings" and "bumps" present in the used CEM/AEM membrane surfaces than were present when imaged new.

\section{Membrane Summary.}

1. MII BPM-9000 and Fumasep® FPM BPMs were selected for testing because even though both were BPMs, they differed in composition, weight, stiffness, thickness, end application use, and cost.

2. Analysis of test data, however, revealed similar performance and water take up properties with results from DoE modeling showing no membrane manufacturer- or end use-related main effect interaction and that temperature was the primary driving factor in terms of the cell output potential.

3. Combined membrane swelling and linkage of the "openings" present in used CEM and AEM membranes aided by the oppositely charged EDL could account for the measured $\mathrm{Cl}^{-}$co-ion/ counter-ion migration across the BPM from concentrated to dilute sides of the functioning BPM concentration cell.
Table 2. BPM ECM: 1:10 MII Room Temperature OCV Data

\begin{tabular}{llc}
\hline Element & Freedom & Value \\
\hline $\mathrm{R}_{\mathrm{ext}}$ & Fixed (X) & $1 \mathrm{E} 09$ \\
$2 \mathrm{R}_{\mathrm{s}}+\mathrm{R}_{\mathrm{m}}$ & Fixed (X) & 2.901 \\
$\mathrm{CPE}-\mathrm{T}$ & Fixed (X) & 0.0031 \\
$\mathrm{CPE}-\mathrm{P}$ & Fixed (X) & 0.764 \\
$\mathrm{R}_{\mathrm{p}}$ & Fixed (X) & 2550 \\
\hline
\end{tabular}

\section{EIS Equivalent Circuit Modeling Discussion}

EIS data are commonly analyzed by fitting the data to an equivalent electrical circuit model (9). To be useful, the elements in the model should have a basis in the physical electrochemistry of the system. As an example, most models contain a resistor that models the cell's internal resistance. Solartron's ZView2 software package was used for both EIS impedance and ECM analysis and display. EIS determined values of the $3.6 \mathrm{M} / / 0.45 \mathrm{M}$ solution resistance $\left(\mathrm{R}_{\mathrm{s}}\right)$ were approximately equal to: $0.33 \mathrm{Ohm}$ for $3.6 \mathrm{M} \mathrm{Cl}^{-}$and $1.41 \mathrm{Ohm}$ for $0.45 \mathrm{M} \mathrm{Cl}^{-}$solutions and $0.69 \mathrm{Ohm}$ for the MII membrane resistance $\left(R_{m}\right)$.

The BPM concentration cell was modeled as a modified Randles' cell (a resistor in series with a parallel $\mathrm{RC}$ circuit) in parallel with an external resistive load $\left(\mathrm{R}_{\text {ext }}\right)$, as presented in Table 2 and Figure 5. BPM ECM-specific modifications include modeling the Randles' cell series resistance as the sum of the internal membrane and solution resistances $\left(2 R_{s}+R_{m}\right)$, and parallel $R C$ circuit as the system polarization resistance $\left(R_{p}\right)$ in parallel with a constant phase element (CPE) interfacial capacitance. The CPE was selected to better model the EDL capacitive effect in the real electrochemical cell. The impedance of the CPE can be expressed (equation 3) as:

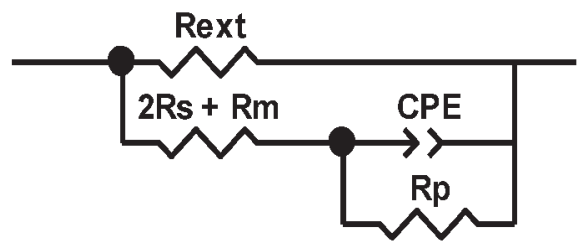

Figure 5. BPM ECM-1:10 MII RT OCV. 


$$
Z=\left(1 / Y_{o}\right)(j \omega)^{-\alpha}(3)
$$

where $Y_{o}=\mathrm{C}=$ the capacitance and $\alpha=$ an exponent that equals 1 for an ideal capacitor and $<1$ for a CPE.

While several theories (surface roughness, "leaky capacitor," nonuniform current distribution, etc.) have been proposed to account for the nonideal behavior of the EDL, $\alpha$ was treated here as an empirical constant with no physical basis until additional research is conducted and a more generally accepted theory put forward.

The Nyquist plot in Figure 6 results from the BPM ECM of Figure 5. Examination of Figure 6 shows a reasonable good fit between OCV modeled and room temperature measured results with the exception being in the extreme low frequency region, which is attributed to local environmental noise contamination. Also evident is the depressed semicircle characteristic of a parallel RC circuit element, which confirms good model compliance.

\section{ECM Model Result Under External Electrical Loading Discussion}

ECM model result comparison analysis was conducted using the same developed OCV ECM with
Table 3. BPM ECM: 1:10 MII RT 500 Ohm External Load Data

\begin{tabular}{lcc}
\hline Element & Freedom & Value \\
\hline $\mathrm{R}_{\text {ext }}$ Free $(+)$ & 500 & \\
$2 \mathrm{R}_{\mathrm{s}}+\mathrm{R}_{\mathrm{m}}$ & Fixed $(\mathrm{X})$ & 2.901 \\
$\mathrm{CPE}-\mathrm{T}$ & Fixed $(\mathrm{X})$ & 0.0031 \\
$\mathrm{CPE}-\mathrm{P}$ & Fixed $(\mathrm{X})$ & 0.764 \\
$\mathrm{R}_{\mathrm{p}}$ & Fixed $(\mathrm{X})$ & 2550 \\
\hline
\end{tabular}

the exception that $R_{\text {ext }}$ was changed from near infinity (1E09) Ohms to $\mathrm{R}_{\mathrm{ext}}=500 \mathrm{Ohms}$, as presented in Table 3. Again no high-frequency semicircle was seen in the Nyquist plot (Fig. 7). Evident again is the depressed semicircle characteristic of a parallel RC circuit element but this time in an externally loaded configuration, again confirming good model compliance. Examination of the Bode plot in Figure 8 reveals a (-) phase angle, which is indicative of a capacitive impedance network.

Diffusional affects, if present, can be identified by the presence of what is termed the Warburg impedance. On a Nyquist plot, the Warburg impedance appears as a diagonal line with a slope of $45^{\circ}$

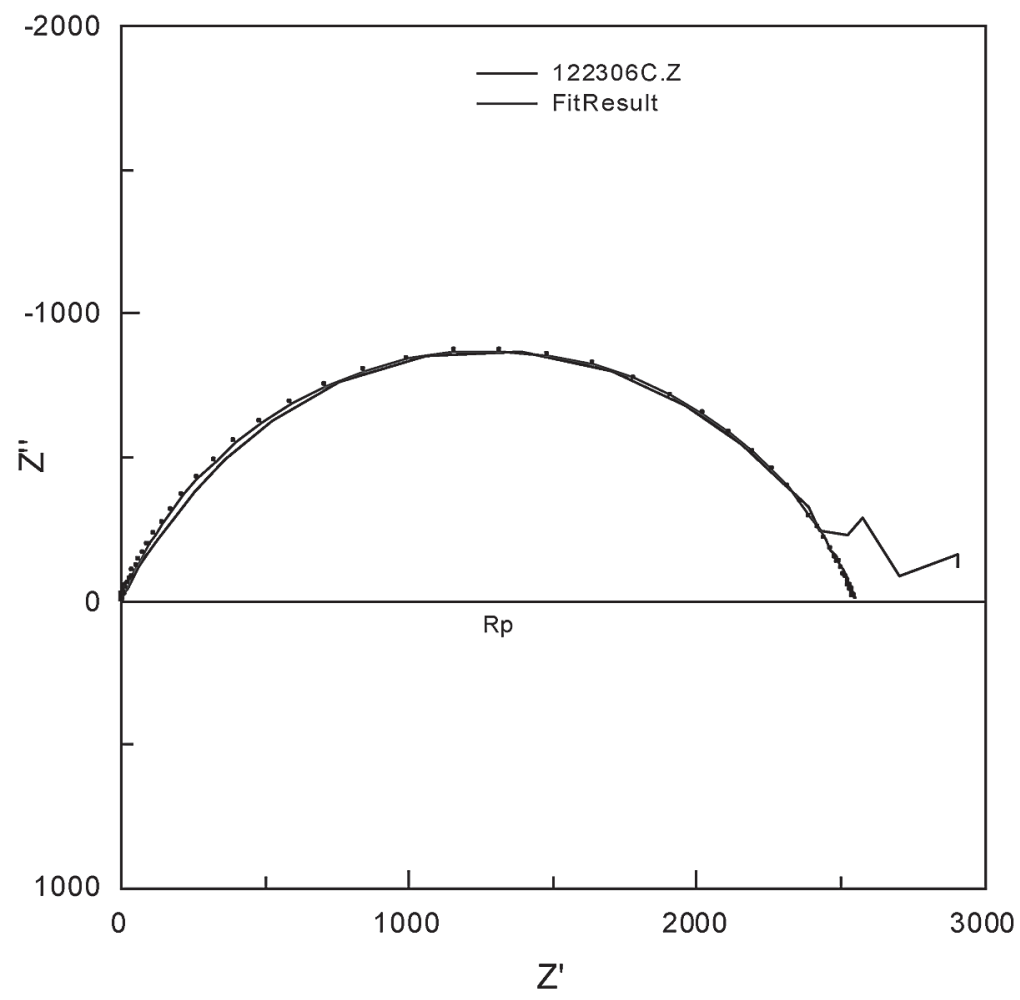

Figure 6. BPM Nyquist plot-1:10 MII RT OCV; measured versus modeled. 


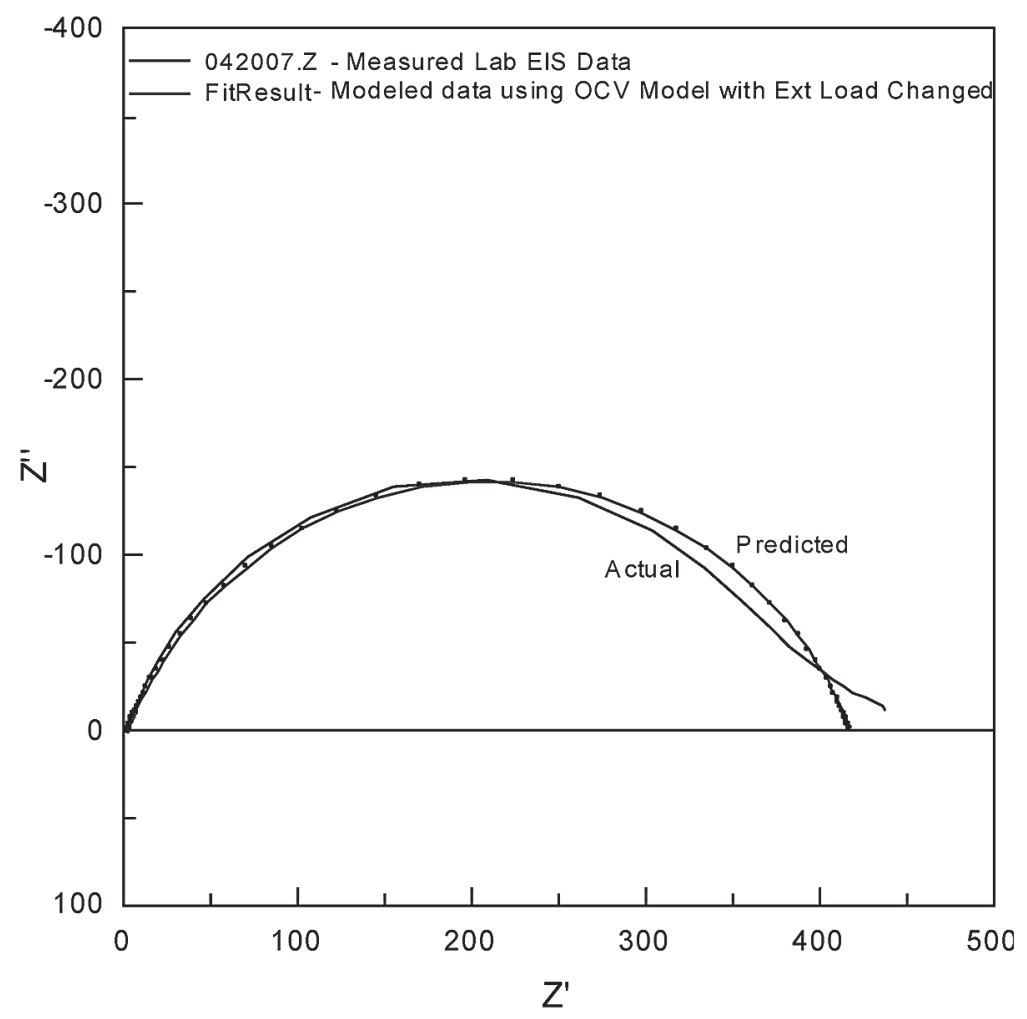

Figure 7. BPM Nyquist plot-1:10 MII RT 500 Ohm external load; measured versus modeled.

at very low frequencies, whereas, on a Bode plot the Warburg impedance exhibits a phase shift of $45^{\circ}$. No evidence of this low-frequency diffusion control was evident in either the Nyquist or Bode plots. This supports the proposed model as primarily a parallel combination of CPE interfacial capacitance and polarization resistance. This, in conjunction, with the corrosion evidence supports belief that $\mathrm{Ag}$ is in equilibrium with its own ions $\mathrm{Ag}^{+}$with the cathodic/anodic reactions occurring at the same rate in each cell side.

\section{BPM Concentration Cell Electrical Loading Discussion}

Cell loading measurements were made on numerous runs using both EIS techniques as well as direct DC monitoring of the cell output potential using a data logger/computer storage system. Representative plots of each are presented in the following sections.

Electrical Loading Comparison. Figure 9 presents a sample 5-day run consisting of both $\mathrm{OCV}$ and varying load conditions. Of significant importance is the consistency and repeatability of conditions, starting at OCV $(69 \mathrm{mV})$, with a $1 \mathrm{~K}$ Ohm load $(18.2 \mathrm{mV})$, then a $500 \mathrm{Ohm}$ load $(8.7$ $\mathrm{mV})$, then a $10 \mathrm{Ohm}$ load $(0.25 \mathrm{mV})$, followed back to OCV $(68 \mathrm{mV})$ and then back to a $500 \mathrm{Ohm}$ load $(8.2 \mathrm{mV})$. This confirms a parallel external load connection with the cell, resulting in a halving of cell output with a halving of externally applied load.

Agitation of the cell was performed at various times before and after this test and although variations did occur in the OCV condition, the affects were small $(<5 \%)$ under load with loaded equilibrium quickly reached once the agitation was removed.

\section{EIS Comparison During Loading}

Figure 10 presents various EIS test results for variations in concentration ratios and external loading values for a standard 80 Mesh MII test configuration run in the $(+)$ membrane orientation convention under solution pumping (nominally 430 $\mathrm{ml} /$ day). With the exception of OCV conditions, no 
applicable difference in measured cell impedance was noted with a 10-fold increase in concentration differences. While a doubling of the applied external load results in an approximate doubling of the cell output membrane potential (parallel connected), a 10-fold increase in solution concentration did not produce a doubling of cell output as predicted by the Nernst equation, thereby illustrating that a BPM concentration cell operation under external loading is not adequately described by the Nernst equation, as is frequently used in individual monopolar CEM and/or AEM investigations.

\section{Solution Pumping Speed Dependency on Cell Output Potential}

The effects of pumping speed on cell performance were evaluated by examining the measured change in a loaded 80 mesh MII 1:10 room temperature test cell operated under fluid pumping speeds of $0.0036 \mathrm{ml} / \mathrm{s}(310 \mathrm{ml} /$ day $)$ to $0.0064 \mathrm{ml} / \mathrm{s}(550$ $\mathrm{ml} /$ day). Data analysis revealed a minimal change in overall cell impendence under a nominal 500
Ohm load and a resulting negligible $1 \mathrm{mV}$ variation in output voltage.

\section{BPM Orientation Discussion}

Membrane output potential and how it varies with membrane side facing orientation (CEM or AEM) was investigated. Figure 11 presents an 8day data plot of a room temperature measurement of $1: 100$ concentration cell membrane potential under the condition of a nominal $500 \mathrm{Ohm}$ external load, 80 mesh electrodes, and a MII membrane.

Figure 11 reveals a significant difference in output membrane potential with membrane orientation as illustrated by the data plots and corresponding orientation layout schematics. For maximum potential output, the cell needs to operate in what is typically referred to as the (+) BPM orientation (the concentrated solution in contact with the BPM AEM side and the BPM CEM in contact with the dilute solution side). Also illustrated in the orientation layout schematics are the measured electrode polarities.
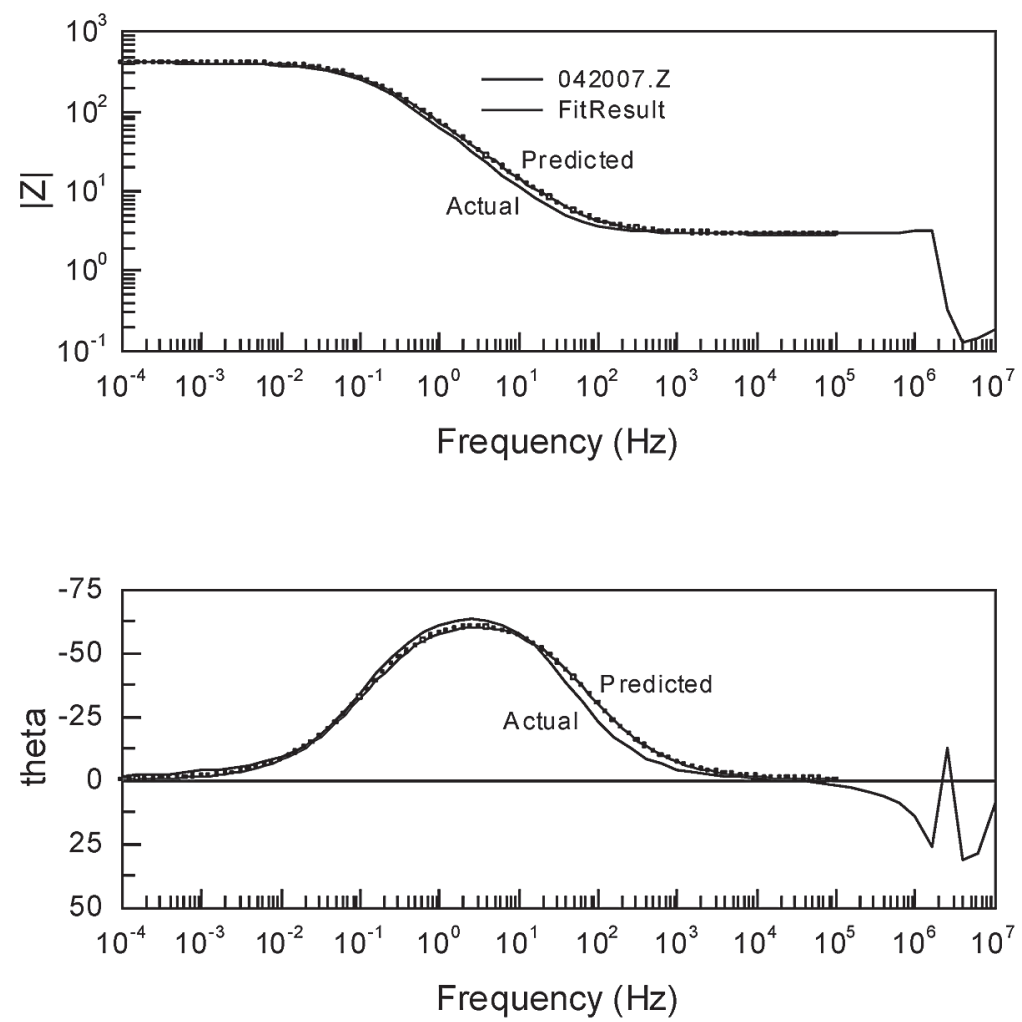

Figure 8. BPM Bode plot-1:10 MII RT 500 Ohm external load; measured versus modeled. 


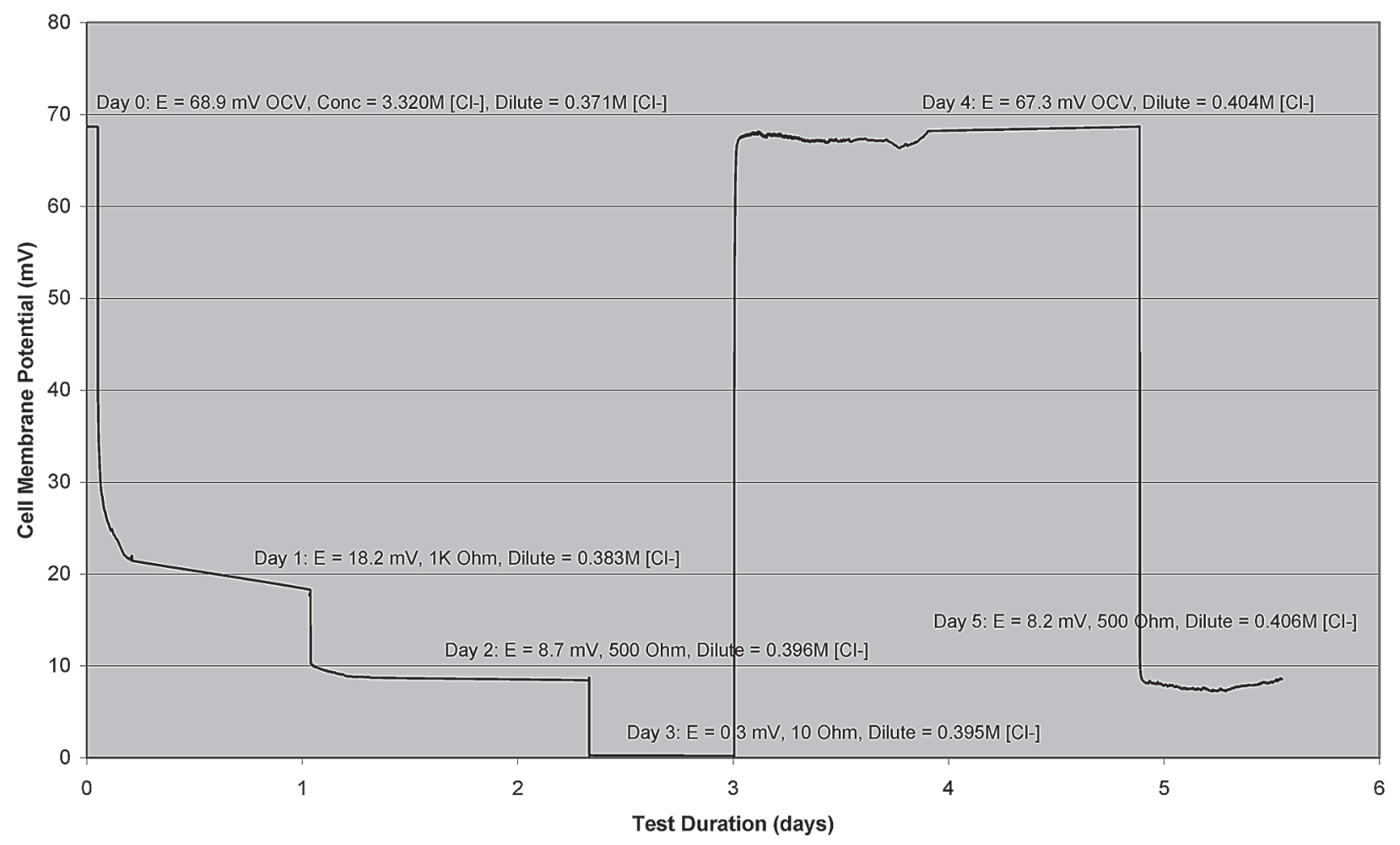

Figure 9. BPM 1:10 MII RT cell loading comparison.

\section{Design of Experiment Modeling Discussion}

Because the Nernst equation did not adequately predict the cell output performance under external loading, a statistical DoE approach was implemented to determine a suitable equation defining the BPM cell loaded output performance. Cell performance testing consisted of a $1 \mathrm{X}$ baseline test fixture (Fig. 12) operated over various test factor variable configurations. The $10 \times 10-\mathrm{cm}\left(4^{\prime \prime} \times 4^{\prime \prime}\right)$ cubic test cell consisted of two symmetrical sections separated by a single BPM. Each section consisted of an end plate, electrode, and test chamber where the concentrated and dilute ionic solutions were exchanged. Solution flow rate was examined separately and found to be negligible at the anticipated low flow rates. External loading effects on cell performance were examined and quantified separately with all testing conducted with an external load of nominally 500 Ohms. Electrode composition variation issues were removed from contributing to the overall cell. Cell agitation was observed to have an effect on the cell potential in the OCV condition but the effect was negligible when an external electrical load was present. This effectively reduced the number of experimental variables down to the following four: 1) electrode surface area (ESA); 2) BPM end use type (MEM); 3) synthetic seawater solution concentration (CONC); 4) cell operating temperature (TEMP).

Because of the number of variables and their coupled parametric interactions, a system of systems based experimental design was created to identify the significant variable(s) driving the delivered output voltage (E1) of the BPM SGP concentration cell.

\section{Test Setup Discussion}

A $2^{4-1}$ fractional factorial design was chosen for this purpose. Using a $2^{4-1}$ design, four variables were studied at two levels by performing eight experiments $\left(2^{4-1}=8\right)$. The response (E1) is the magnitude of the concentration cell output voltage in $\mathrm{mVDC}$ operated in the $(+)$ membrane orientation and under an external electrical load of nominally 500 Ohms. The design of experiment matrix (Table 
4) shows the measured response along with the two levels of the variables coded such that a minus one $(-1)$ represents the low level and a plus one $(+1)$ represents the high level. These variables and coded levels were chosen based on previous experiments and practical considerations anticipated to be encountered in actual SGP field operations.

\section{BPM DoE Predictive Model Results}

The results of this 7 degree of freedom $(d f)$ analysis were used to develop an equation that shows the cell parameter interrelationships between ESA, MEM, CONC, and TEMP.

$$
\begin{aligned}
\mathrm{E} 1= & 13.825+4.775 * \mathrm{ESA}+0.525 * \mathrm{MEM} \\
& -3.525 * \mathrm{CONC}+9.575 * \mathrm{TEMP}-4.025 \\
& * \mathrm{ESA} \text { MEM }+0.925 * \mathrm{ESA} \text { CONC } \\
& +4.025 * \mathrm{ESA} * \mathrm{TEMP}
\end{aligned}
$$

Inspection of equation 5 shows that cell temperature is the most important independent factor affecting cell output voltage and the interaction between ESA and CONC the least important. In order to obtain standard error (SE) and 95\% confidence interval (CI) data, the lowest contributing two-way interaction effect was removed and a $6 d f$ analysis rerun with the resulting predictive equation presented in equation 6 .

$$
\begin{aligned}
\mathrm{E} 1(\mathrm{SE})[ \pm \mathrm{CI}]= & 13.825+4.775 * \mathrm{ESA} \\
& +0.525 * \mathrm{MEM}-3.525 * \mathrm{CONC} \\
& +9.575 * \mathrm{TEMP}-4.025 * \mathrm{ESA} \\
& * \mathrm{MEM}+4.025 * \mathrm{ESA} * \mathrm{TEMP}
\end{aligned}
$$

The values of ESA are either -1 (low, 80 mesh) or +1 (high, 40 mesh); values of MEM are either (low, Fumasep ${ }^{\circledR}$ ) or +1 (high, MII); values of CONC are either -1 (low, 1:100) or +1 (high, 1: 10 ); and values of TEMP are either -1 (low, $\left.5^{\circ} \mathrm{C}\right)$ or +1 (high, $40^{\circ} \mathrm{C}$ ). With 80 mesh electrodes, MII membrane, 1:100 concentration, and room temperature (RT), equation 6 predicts:

$$
\begin{aligned}
\mathrm{E} 1= & 13.825+4.775^{*}(-1)+0.525^{*}(+1) \\
& -3.525 *(+1)+9.575^{*}(0)-4.025^{*}(-1) \\
& *(+1)+4.025^{*}(-1) *(0)=10.1 \mathrm{mV} \\
& (\mathrm{SE}=2.068,95 \% \mathrm{CI}=-16.2,36.36)
\end{aligned}
$$

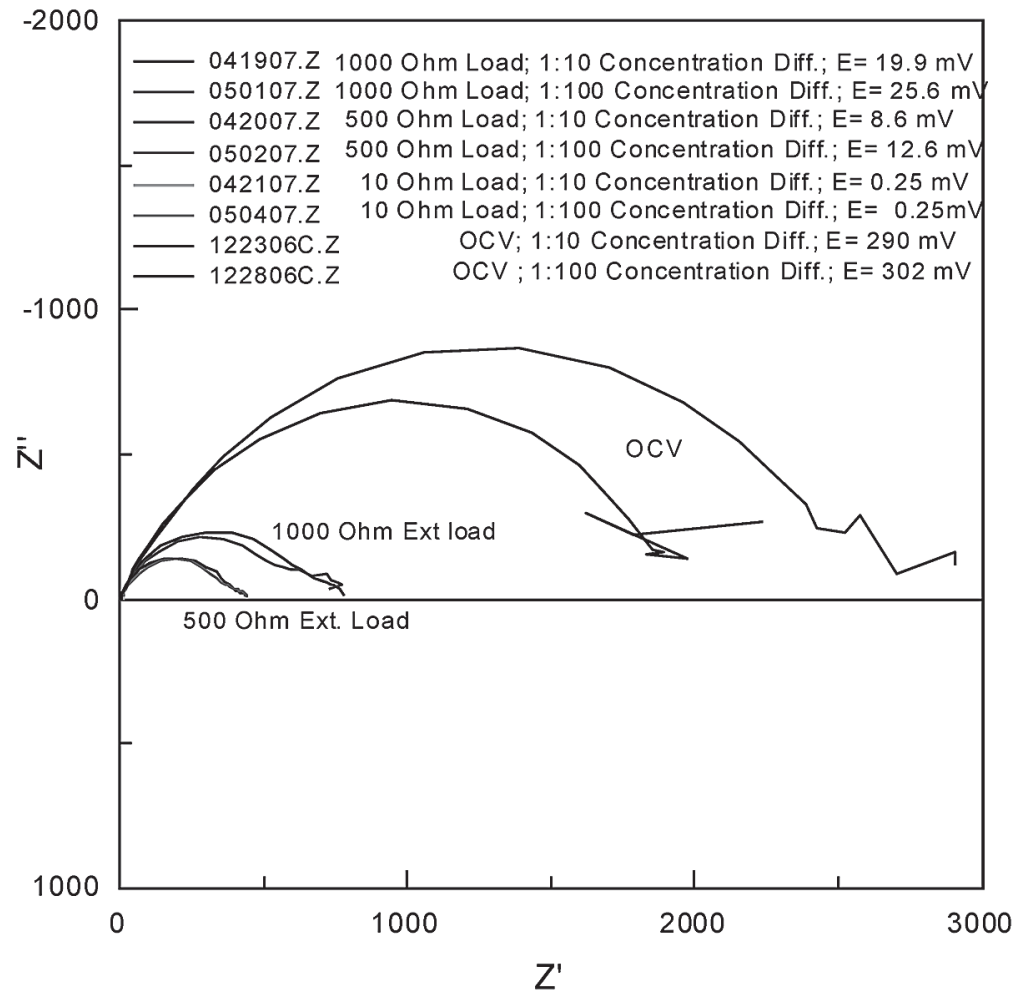

Figure 10. BPM EIS load comparison plot. 

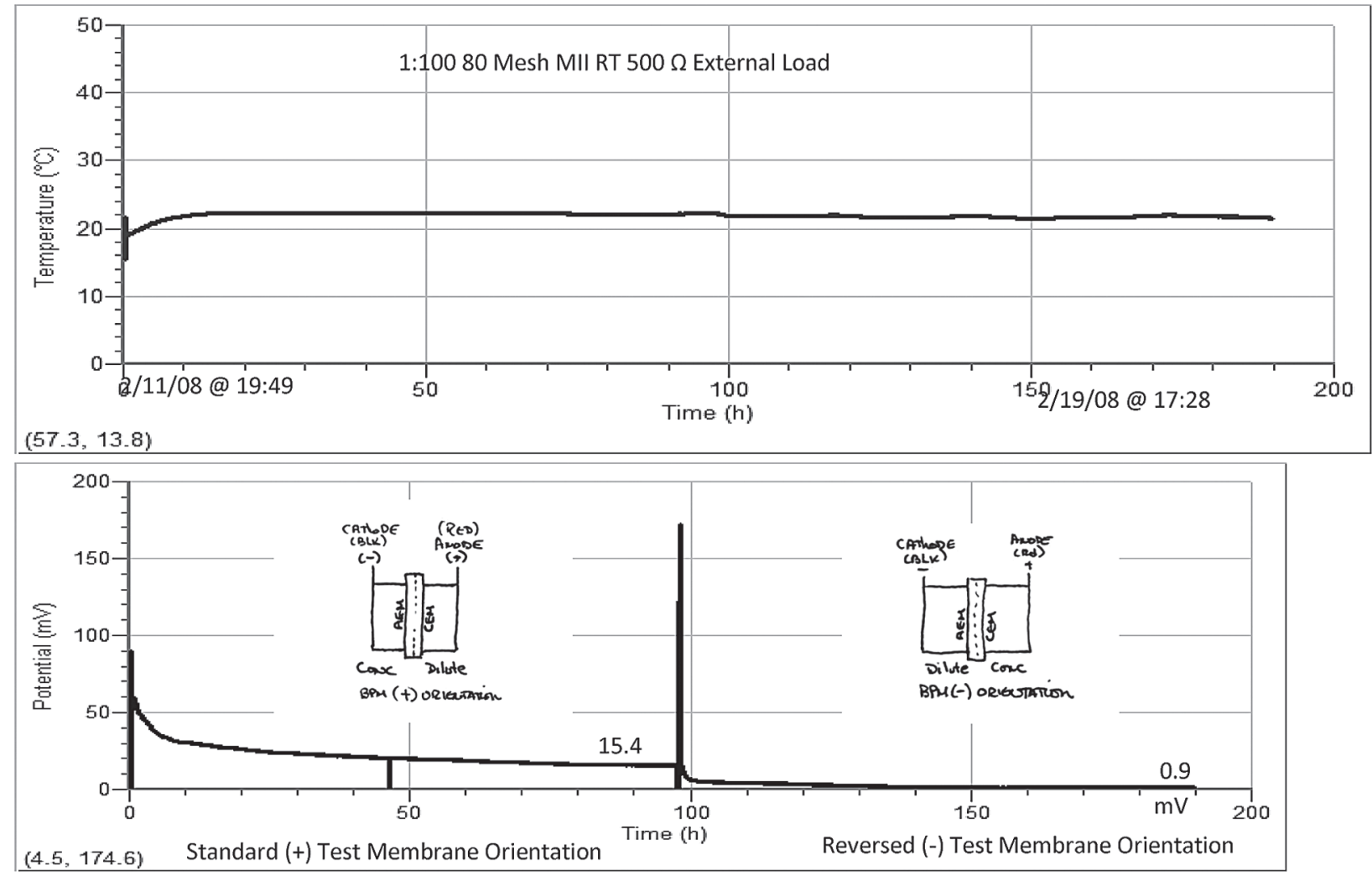

Figure 11. 1:100 MII 80 mesh BPM orientation test.

This compares favorably to the actual measured result of $15.5 \mathrm{mV}$ presented in Figure 11 for this condition. Similarly, with 40 wire mesh Ag electrodes, MII membrane, 1:100 concentration, and RT operation, equation 6 predicts:

$$
\begin{aligned}
\mathrm{E} 1= & 11.6 \mathrm{mV}(\mathrm{SE}=2.068 \\
& \text { and } 95 \% \mathrm{CI}=-14.7,37.86)
\end{aligned}
$$

This compares favorably to the actual measured result of $13.7 \mathrm{mV}$ during scalability testing discussed later in this article.

\section{BPM Concentration Cell Series/Parallel Testing Results}

The baseline $1 \mathrm{X}$ test apparatus is a single cubicshaped cell (Fig. 12). Although a single cell was

Table 4. BPM Engineering Design Test Results with 500 Ohm External Loading

\begin{tabular}{llllllrr}
\hline Run & ESA & M & Conc. & Temp. & Date & $\begin{array}{r}\text { Temp. } \\
\left({ }^{\circ} \mathrm{C}\right)\end{array}$ & $\begin{array}{c}\text { Cell Voltage } \\
(\mathrm{mV} \mathrm{DC})\end{array}$ \\
\hline 1 & $80(-1)$ & FUM (-1) & $1: 100(-1)$ & L $(-1)$ & $10 / 29 / 07$ & 4.6 & 3.4 \\
2 & $40(1)$ & FUM (-1) & $1: 100(-1)$ & H (1) & $11 / 03 / 07$ & 38.9 & 38.3 \\
3 & $80(-1)$ & MII (1) & $1: 100(-1)$ & H (1) & $1 / 26 / 08$ & 38.9 & 23.6 \\
4 & $40(1)$ & MII (1) & $1: 100(-1)$ & L (-1) & $1 / 23 / 08$ & 3.6 & 4.1 \\
5 & $80(-1)$ & FUM (-1) & $1: 10(1)$ & H (1) & $10 / 31 / 07$ & 40.4 & 5.6 \\
6 & $40(1)$ & FUM (-1) & $1: 10(1)$ & L (-1) & $10 / 30 / 07$ & 4.5 & 5.9 \\
7 & $80(-1)$ & MII (1) & $1: 10(1)$ & L (-1) & $9 / 27 / 07$ & 3.1 & 3.6 \\
8 & $40(1)$ & MII (1) & $1: 10(1)$ & H (1) & $10 / 18 / 07$ & 38.9 & 26.1 \\
\hline
\end{tabular}




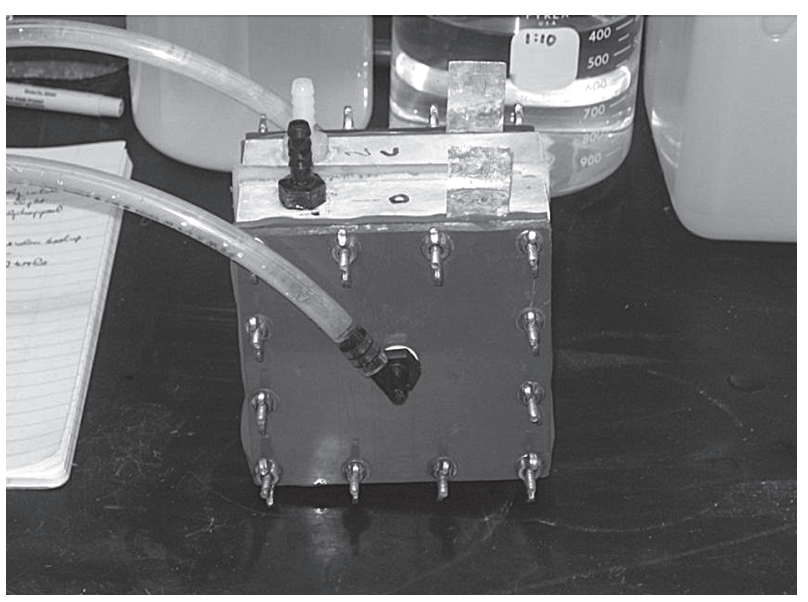

Figure 12. Standard 1X BPM concentration test cell.

initially evaluated, it was envisioned that a plurality of sequentially spaced cells, electrically connected in differing series/parallel configurations will ultimately be required to generate the desired output power. During subsequent testing, it was found that individual cells when connected in serial/parallel combinations acted as any battery does, where serial voltages and parallel currents sum together. However, when multiple membranes where configured in a basic ED stack (manifoldlike) configuration, this was found not to be the case. The reason for this was determined to be related to the BPM orientation effects.

As discussed, BPMs exhibit a preferred orientation to achieve maximum results-in this case the "+" orientation-where the CEM membrane side is in contact with the dilute saline solution and the AEM membrane side is in contact with the concentrated saline solution. Because of this, when multiple membranes are used sequentially in a single device, every other membrane must be physically reversed in order for the dilute and concentrated solution streams to be in proper contact with the appropriate membrane side. This effectively "shorts" out the intermediate membranes and increases the overall internal impedance such that the measured overall electrically loaded cell output was observed to be actually less than a single membrane output. Tests with single BPM and three BPM RED stack test configurations were conducted, as shown in Figure 13, with the designated $+/-$ electrode configurations illustrated.
The measured 1X, 1:100, 40 Ag mesh, MMI BPM, RT test results are presented in Figure 14 and summarized in Table 5. Table 5 data show that the total output from the three BPM RED stack series configuration is approximately a third (over an external load range of 465 to $9990 \mathrm{Ohm}$ ) of the single cell output. This unfortunately means that multi-BPMs utilized in a traditional single RED series cell stack configuration won't work nor can BPMs be used as direct drop in AEM/CEM replacements in existing RED systems. Rather, configurations consisting of numerous individual cells connected in series or parallel configurations will be required to obtain desired performance output.

Using the data from Table 5, estimates of the resulting power density $\left(\mathrm{W} / \mathrm{cm}^{2}\right)$ were computed and are presented in Table 6. Table 6 data summarize the reduced BPM output power density performance when used in a single series RED stack configuration as well as the magnitude of the resulting average power density for each case.

\section{BPM Concentration Cell Membrane Scalability Testing Results}

The standard $1 \mathrm{X}$ baseline single membrane test cell $[10 \times 10 \mathrm{~cm}$ outer dimensions (approximately $7 \times 7 \mathrm{~cm}$ inner dimensions with a wetted BPM area of $47.7 \mathrm{~cm}^{2}$ )] used throughout this testing effort was again used here for baseline comparison. Additional test cell configurations were designed and constructed to reflect approximate exposed membrane solution area sizes of $0.34 \mathrm{X}$ and $3.54 \mathrm{X}$ times the baseline, for the purpose of determining any BPM wetted surface area dependency on loaded cell output voltage and power density. Test results are presented in Figure 15 and summarized in Table 7.

Examination of the Table 7 data reveals a BPM wetted surface area dependence but results differ depending upon the value of the supplied external resistance, as seen in previous single versus RED stack manifold testing. While Figure 15 shows that higher loaded cell voltage outputs occur with increasing area, the overall power density relationship is not linear. Using the data from Table 7, estimates of the resulting power density $\left(\mathrm{W} / \mathrm{cm}^{2}\right)$ were computed and presented in Table 8. The individual power densities versus $R_{\text {ext }}$ are presented in Figure 


$$
\begin{array}{c|c}
+ & \\
\text { Dil } & \text { Conc } \\
\text { CEM } & \text { AEM }
\end{array}
$$

Single BPM Configuration

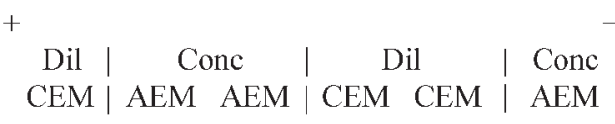

Three BPM RED Stack Manifold Configuration

Figure 13. Single BPM and three BPM configurations.

16 with the corresponding average power density values presented in Figure 17.

Analysis of the Figure 16 power density data suggests the existence of an external load/maximum output relationship. Similarly, as shown in Figure 17, the measured 1X peak power condition $\left(12.9\right.$ nanoW/ $\left./ \mathrm{cm}^{2}\right)$ is approximately $25 \%$ higher than the $3.54 \mathrm{X}\left(9.8\right.$ nanoW/ $\left./ \mathrm{cm}^{2}\right)$ test results. Additional data are needed to elucidate this relationship.

\section{BPM Concentration Cell Water Flux Transport Discussion}

Visual evidence of direct (anomalous positive) osmosis, confirming the migration of water moving across the BPM from the dilute side to the concentrated side, was observed during numerous $1 \mathrm{X}$ test trials at standard room temperature and pressure. In addition, $\mathrm{Cl}^{-}$ion migration across the $\mathrm{BPM}$ from the concentrated to dilute side cell was confirmed via numerous $\mathrm{Cl}^{-}$titration measurements (with some of the data presented in Fig. 9).

Detailed analysis using the $3.54 \mathrm{X}$ test fixture was conducted to determine the amount of water transfer via direct osmotic pressure and whether this transfer could be harnessed to do useful work. To accomplish this, the test fixture was slightly modified in that instead of circulating the concentrate via pumping from/to the reserve container, a 1/4-in. ID vertical tube was attached to the exit port of the cell and water was monitored as it rose and exited the tube. Several conditions were monitored, under $465 \mathrm{Ohm}$ of load with only dilute pumping occurring (to ensure that the dilute cell was full and the entire wetted area covered) and

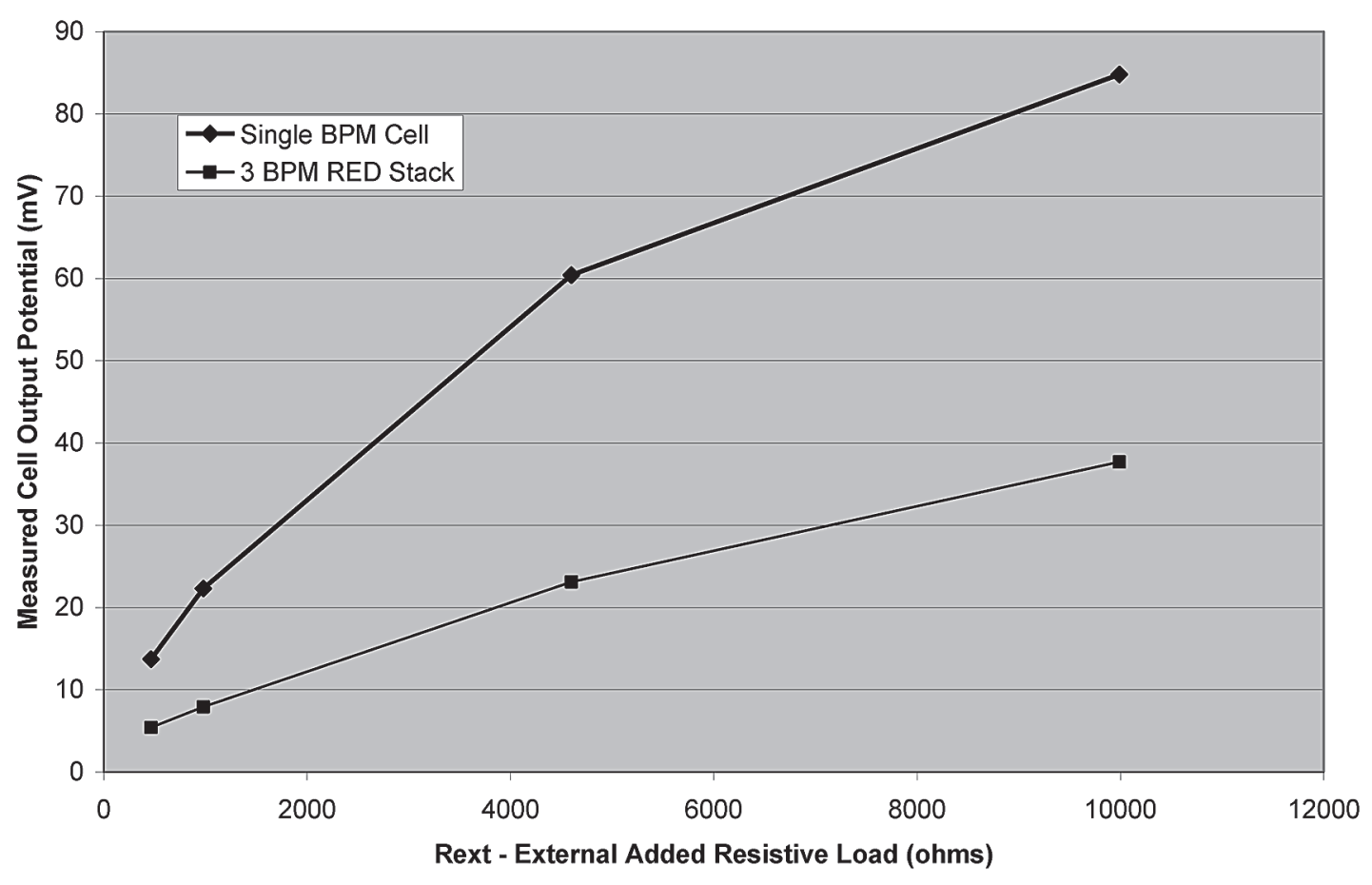

Figure 14. Single BPM cell versus three BPM cell RED stack test results. 
Table 5. Single BPM Cell Versus Three BPM Cell RED Stack Versus $\mathrm{R}_{\text {ext }}$ Test Results

\begin{tabular}{lrrrr}
\hline Configuration & $465 \mathrm{Ohm}$ & $980 \mathrm{Ohm}$ & $4600 \mathrm{Ohm}$ & $9990 \mathrm{Ohm}$ \\
\hline Single BPM & $13.7 \mathrm{mV}$ & $22.3 \mathrm{mV}$ & $60.4 \mathrm{mV}$ & $84.8 \mathrm{mV}$ \\
Three BPM Stack & $5.4 \mathrm{mV}$ & $7.9 \mathrm{mV}$ & $23.1 \mathrm{mV}$ & $37.7 \mathrm{mV}$ \\
\hline
\end{tabular}

under no load (OCV) with both pumping and nonpumping conditions, with details presented in Figure 18. Examination of the Figure $18 \mathrm{OCV}$ test results reveals a near constant linear slope of the run time versus vertical height curves, which was independent of whether or not the dilute solution was being pumped (cycled) through the dilute cell compartment.

Evaluation of Figure 18 results reveals that under both conditions, water rose in the vertical tube at an uniform rate and exited the tube into a beaker above the test cell (height limitation imposed by the test location selected, not a limit by the system, which could have been higher). This fluid represents a potential energy storage reservoir that can be recovered and later used to do work. In addition, at one point in the test program, the tube end was plugged with vertical height movement stopped. Upon removal of the tube, the water immediately rose to its near prior predicted height. This jet-like impulse could also be used to recover kinetic energy from the system.

Continued examination of the Figure 18 test results revealed that the $\mathrm{OCV}$ unloaded through BPM flow rate average over the 2-day test was $0.69 \mathrm{in} . / \mathrm{h}\left(1.5 \mathrm{E}-10 \mathrm{~m}^{3} / \mathrm{s}\right)$, whereas the $465 \mathrm{Ohm}$ loaded through BPM flow rate average over the 2day test was $0.55 \mathrm{in} . / \mathrm{h}\left(1.2 \mathrm{E}-10 \mathrm{~m}^{3} / \mathrm{s}\right)$. This

Table 6. Computed BPM Power Density: Single Versus Three BPM Cell RED Stack

\begin{tabular}{lcc}
\hline & $\begin{array}{c}\text { Single BPM } \\
\text { Cell Power } \\
\text { Density } \\
\left(\mathrm{W} / \mathrm{cm}^{2}\right)\end{array}$ & $\begin{array}{c}\text { Three BPM } \\
\text { Cell RED } \\
\text { Stack Power } \\
\text { ext }\end{array}$ \\
\hline 465 & $\begin{array}{c}\text { Density } \\
\left(\mathrm{W} / \mathrm{cm}^{2}\right)\end{array}$ \\
980 & $8.46549 \mathrm{E}-09$ & $4.38407 \mathrm{E}-10$ \\
4600 & $1.06426 \mathrm{E}-08$ & $4.45216 \mathrm{E}-10$ \\
9990 & $1.66334 \mathrm{E}-08$ & $8.10977 \mathrm{E}-10$ \\
Average & $1.5097 \mathrm{E}-08$ & $9.94626 \mathrm{E}-10$ \\
\hline
\end{tabular}

revealed that the flow rate varied under external electrical loading. Also monitored during the testing was the average cell output voltage of approximately $11 \mathrm{mV}$ under $465 \mathrm{Ohms}$ of external resistive load. Although lower in value than the nonmodified $3.54 \mathrm{X}$ cell output value of $25.9 \mathrm{mV}$ (without the vertical tube addition), it suggests that operation of the cell in both modes is possible. Additional testing is necessary to see how the water flux transport, output voltage, and power density vary at other electrical loading conditions.

In summary, testing confirmed water flux transport through the BPM from the dilute to the concentrated side with the flow rate varied/regulated by externally applied electrical loading. In addition, it was shown that the transported solvent could be used to "pump" water vertically up to a reservoir for later potential energy recovery/use and could also be used for kinetic energy impulse recovery/use. Finally, it was shown that the water flux transport can occur concurrently with the generation of electrical energy via ion transport from the concentrated to the dilute side (patent pending).

\section{BPM SUMMARY RESULT DISCUSSION}

\section{BPM SGP Basic Research Test Results Discussion}

Based on our research findings thus far:

1. Because of side facing orientation effects, BPMs do not appear suitable as a direct drop in replacement in existing compact, multiconcentric monopolar AEM/CEM RED systems. They rather will require numerous individual cells connected in series or parallel configurations to get the required performance output.

2. At the maximum peak power point measure for the $1 \mathrm{X}$ configuration at $4600 \mathrm{Ohms}$, it would take $6,102,374$ cells to make $1.65 \mathrm{~W}$ (assuming no other losses are encountered). 


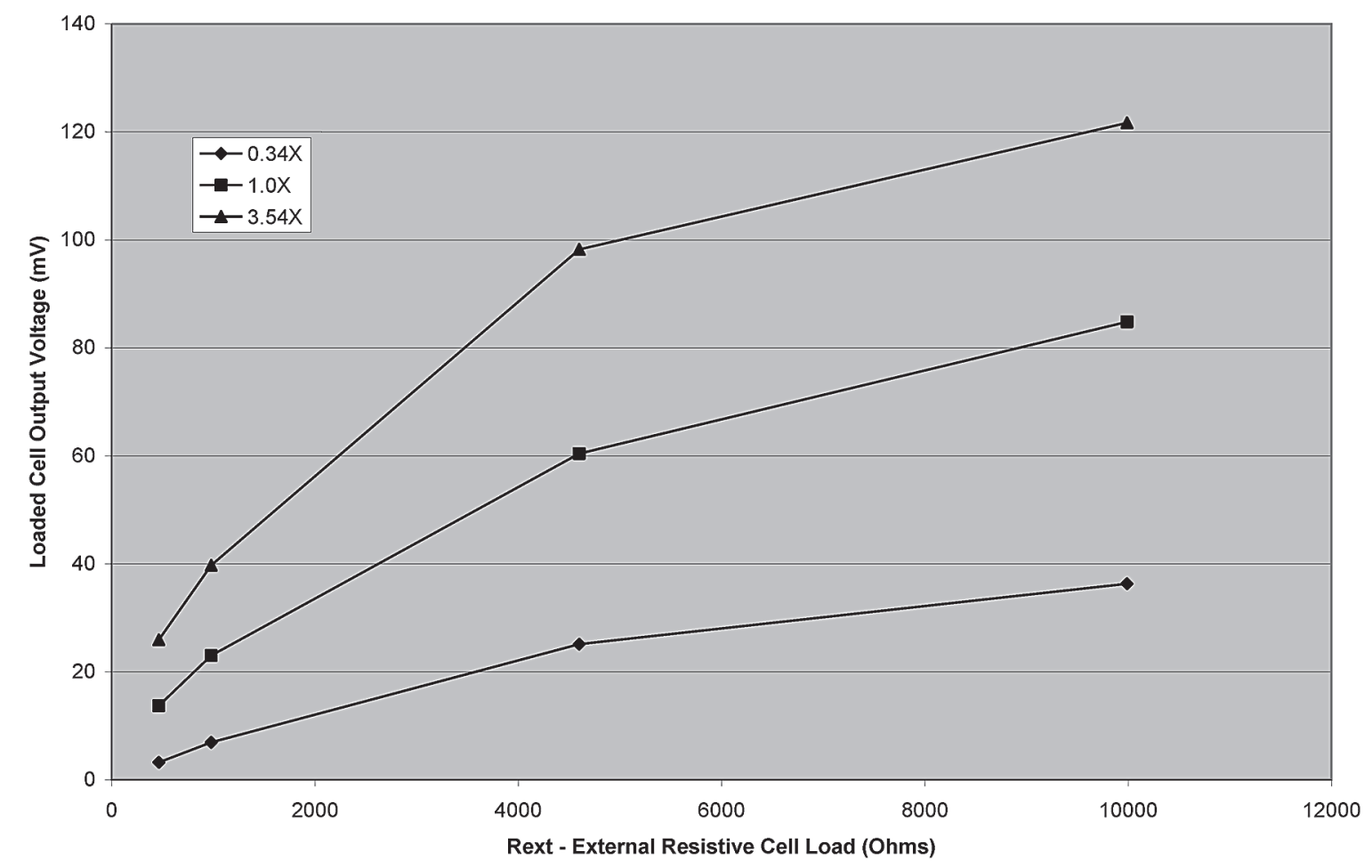

Figure 15. BPM wetted surface area performance test results.

3. For the same $1.65 \mathrm{~W}$, it would take $1,186,605$ of the lower dower density $3.54 \mathrm{X}$ cells at 4600 Ohms, or a 5.14 times reduction in required cells.

4. Although 5.14 times less cells is a significant improvement, it is still 1,186,605 1X sized cells and then only for $1.65 \mathrm{~W}$. What is more feasible? A single cell with a square football field of contact membrane area or tens/thousands/hundred of thousands/millions of smaller cells?

Clearly, the present opportunity for high saline BPM-based SGP generation appears not to be the solution to large scale (utility) PRO or RED energy production needs. The BPMs evaluated thus far

Table 7. Cell Output Versus Various Externally Applied Resistive Loads: $\mathrm{R}_{\mathrm{ext}}$

\begin{tabular}{lrccc}
\hline Configuration & $\begin{array}{c}465 \\
\text { Ohm }\end{array}$ & \multicolumn{1}{c}{$\begin{array}{c}\text { Ohm } \\
\text { Ohm }\end{array}$} & $\begin{array}{c}4600 \\
\text { Ohm }\end{array}$ & \multicolumn{1}{c}{$\begin{array}{c}\text { Ohm } \\
\text { Ohm }\end{array}$} \\
\hline Single 0.34X BPM & $3.2 \mathrm{mV}$ & $6.9 \mathrm{mV}$ & $25.1 \mathrm{mV}$ & $36.3 \mathrm{mV}$ \\
Single 1X BPM & $13.7 \mathrm{mV}$ & $22.3 \mathrm{mV}$ & $60.4 \mathrm{mV}$ & $84.8 \mathrm{mV}$ \\
Single 3.54X BPM & $25.9 \mathrm{mV}$ & $39.7 \mathrm{mV}$ & $98.2 \mathrm{mV}$ & $121.7 \mathrm{mV}$ \\
\hline
\end{tabular}

were, as in initial PRO and RED investigations, not optimized for SGP purposes and, as such, are conceptually at the $0.1 \mathrm{~W} / \mathrm{m}^{2}$ starting point originally seen in initial PRO testing. However, although currently low in output, BPMs exhibit both water flux and ionic transport capabilities in the same membrane and for that offer promise in future SGP applications. BPM-based SGP production is in its

Table 8. Computed BPM Power Density: 0.34X Versus 1X Versus 3.54X Area Ratio

\begin{tabular}{lccc}
\hline & $\begin{array}{c}\text { 0.34X BPM } \\
\text { Cell Power } \\
\text { Density } \\
\mathrm{R}_{\text {ext }}\end{array}$ & $\begin{array}{c}\text { 1X BPM } \\
\text { Cell Power } \\
\text { Density } \\
\left(\mathrm{W} / \mathrm{cm}^{2}\right)\end{array}$ & $\begin{array}{c}\text { 3.54X BPM } \\
\text { Cell Power } \\
\text { Density } \\
\left(\mathrm{W} / \mathrm{cm}^{2}\right)\end{array}$ \\
\hline 465 & $1.34383 \mathrm{E}-09$ & $8.46549 \mathrm{E}-09$ & $8.55503 \mathrm{E}-09$ \\
980 & $2.96463 \mathrm{E}-09$ & $1.06426 \mathrm{E}-08$ & $9.54663 \mathrm{E}-09$ \\
4600 & $8.35773 \mathrm{E}-09$ & $1.66334 \mathrm{E}-08$ & $1.24453 \mathrm{E}-08$ \\
9990 & $8.04909 \mathrm{E}-09$ & $1.5097 \mathrm{E}-08$ & $8.79035 \mathrm{E}-09$ \\
Average & $5.2 \mathrm{nanoW}^{2} \mathrm{~cm}^{2}$ & $12.9 \mathrm{nanoW} / \mathrm{cm}^{2}$ & $9.8 \mathrm{nanoW} / \mathrm{cm}^{2}$ \\
\hline
\end{tabular}

Proposal Number N072-144-0319 Dialytics, Inc. PROPRIETARY Topic Number N07-144 


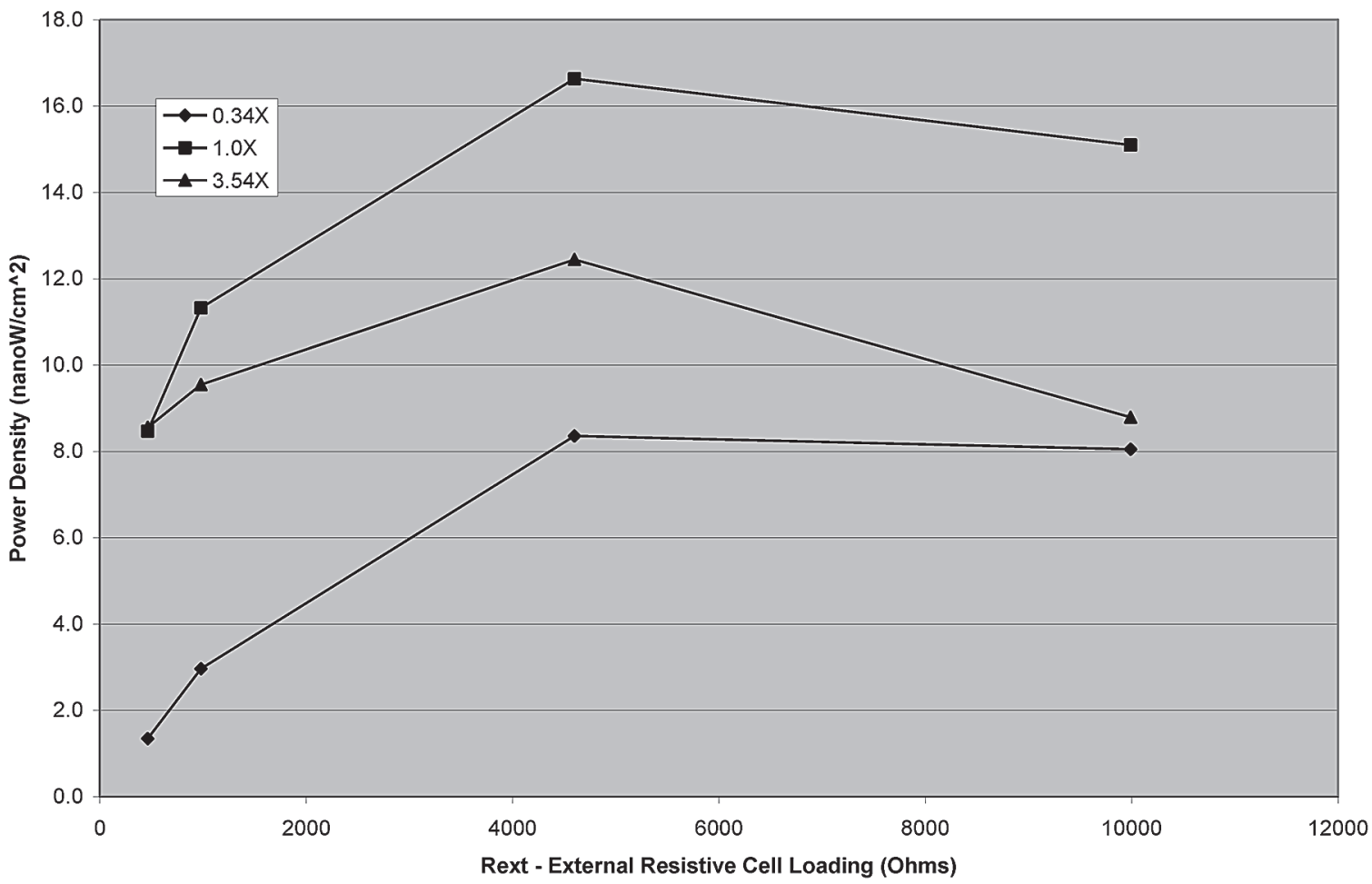

Figure 16. BPM power density versus surface area versus $\mathrm{R}_{\text {ext }}$ performance test results.

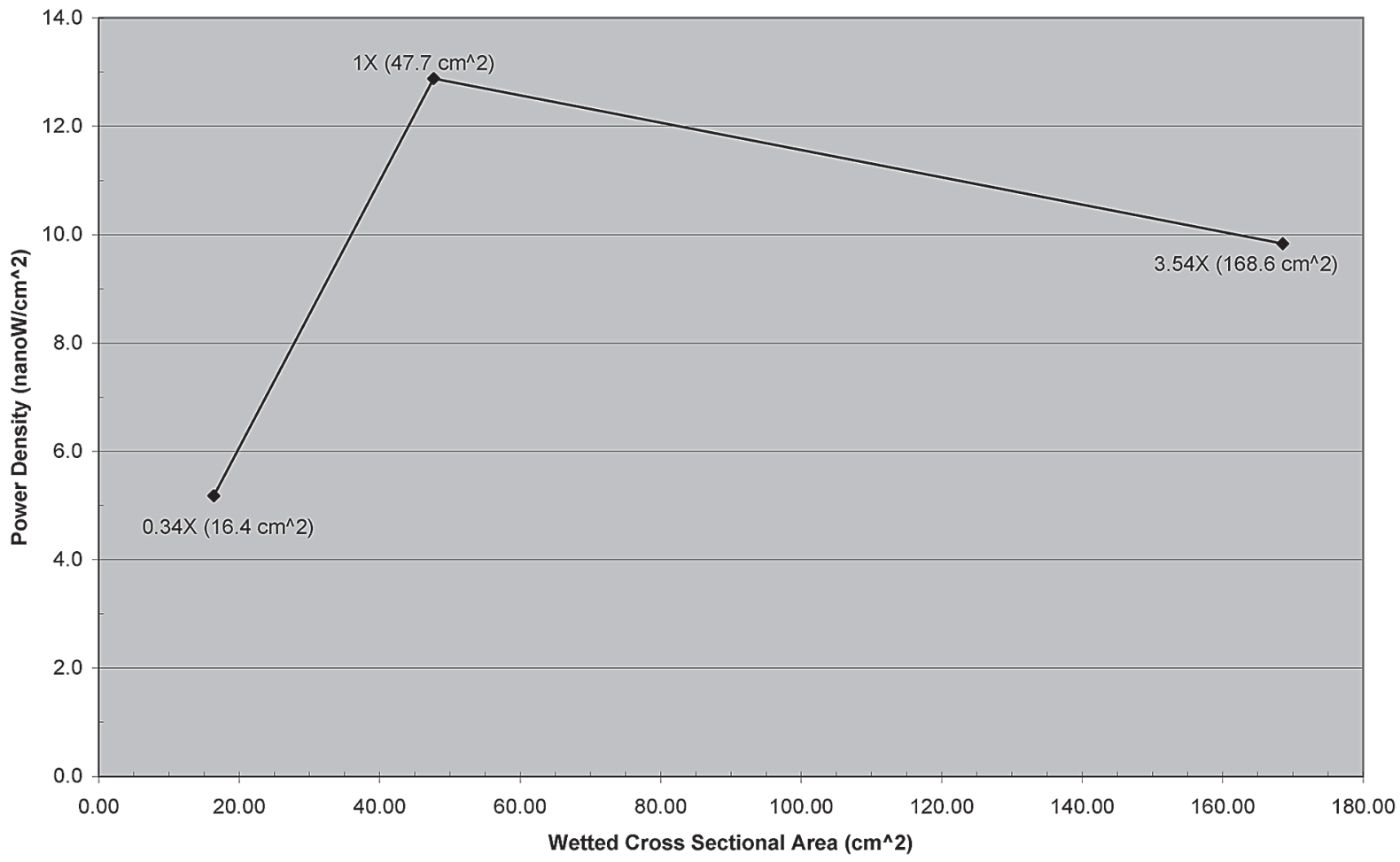

Figure 17. BPM power density versus surface area summary plot. 


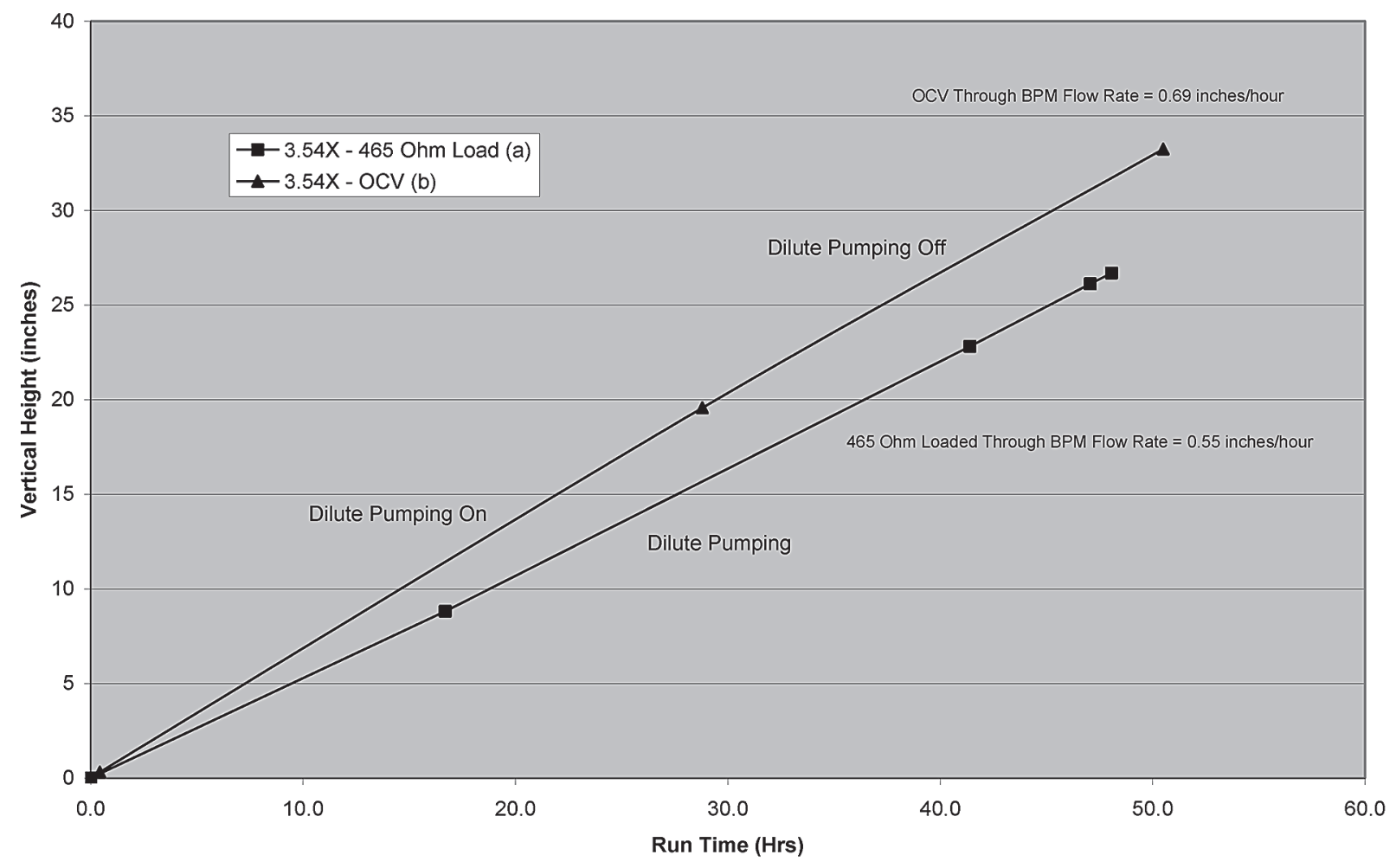

Figure 18. BPM concentrated water level vertical height plot: OCV versus 465 Ohm load.

infancy. And along with the other SGP membranebased solutions discussed herein, additional SGPfocused applied research and development is needed.

\section{Current and Future State of BPM-Based SGP}

In conjunction with a strong BPM R\&D effort, one must also look to other options of the energy production spectrum and evaluate their suitability based on product need, fully recognizing that although BPM-based power generation using diffusion gradients currently offer very small generated output power, the energy production is continuous, sustainable, and renewable. As in any renewable solution, energy storage for on-demand use is required. Crucial as well is the identification of practical end markets and solutions. One such application may be the use of this technology as a possible power source for extremely low-power systems such as energy harvesting devices (EHD) or related low-power applications where it is impossible or impractical to provide wired or traditional battery power.
Energy harvesting has grown from long-established concepts into devices for powering ubiquitously deployed sensor networks and mobile electronics. Energy harvesting legacy dates to the water wheel and windmill; credible approaches that scavenge energy from waste heat or vibration have been around for many decades. Recently the field has encountered renewed interest as low-power electronics, wireless standards, and miniaturization populate the world with mobile devices. There has been considerable research interest in the development of large-scale, distributed sensor networks. This interest has been fueled in part by the anticipated future availability of small, inexpensive, low-power network computing and wireless communication devices. Conceptually, the combination of such devices and traditional sensor technology provide the physical components needed to form the foundation of the envisaged sensor networks. A small sensor network node with sensing, processing, storage, and communication capabilities could be either completely self-contained or integrated into other equipment, and a large number of such 
nodes could be deployed in an area of interest and networked together to collect information (e.g., rapid environmental assessment).

In addition, wireless sensor networks (WSN) hold significant potential in the industrial environment. Before wireless industrial sensors can be deployed in large numbers, there is a need for improved methods for powering these devices. Wireless technology is revolutionizing the industrial instrumentation world. However, the idea of periodically replacing batteries in thousands of wireless devices throughout an industrial complex is not attractive. The small-scale supplemental power generation (such as direct and energy recovery devices used in power generation and desalination plants, which are typically collocated and have access to saline solutions of differing concentrations) is a possible solution to this niche opportunity. For WSN to achieve true ubiquitous deployment, the size, cost, and power consumption of the nodes must decrease dramatically while the intelligence of the network increases (53).

Besides being a potential renewable energy conversion technology for smart sensor networks, this renewable instant energy has uses in a wide variety of applications and size scales depending upon the source of the supplied ionic solutions and the anticipated scale/end use of the system. Some of these applications include: small-scale supplemental power generation (such as direct and energy recovery devices used in power generation and desalination plants, which are typically colocated); mediumscale ocean monitoring for coastline states or for buoy systems for Coast Guard, NOAA, and Tsunami warning systems; large-scale direct commercial power generation systems using naturally occurring salinity gradient differences such as those found where rivers discharge into the sea.

\section{CONCLUSION AND FUTURE NEEDS}

Energy drives the global economy, and renewable sources have again come into intense focus but this time hopefully with more realistic estimations of their supplementary contributions to the overall energy solution. SGP is instantly available when diluted and concentrated ionic solutions are mixed; is renewable, sustainable, and produces no $\mathrm{CO}_{2}$ emissions or other significant effluents that may interfere with global climate. SGP possesses not only the largest energy potential of the traditional marine sources but likely the largest total available resource as well, especially when combining marine with waste/other brine options. Considering the vastness of the potential resources available, even inefficient extraction could be acceptable as long as there is an adequate return on the investment. The transformative research required remains the continued advancement in the knowledge and understanding of SGP both within and across related scientific fields lay in the generation, supply, and storage of the power needed by the sensors and monitoring/sensing system it serves.

Although BPM-based SGP generation is currently low in output power density, BPMs exhibit both water flux and ionic transport capabilities and, for that, offer promise in future SGP applications. BPM-based SGP production is in its infancy and, along with the other SGP membrane-based solutions discussed herein, require additional SGPfocused applied research and development. To further develop this exciting technology, several things are required:

1. Inclusion of the term "salinity gradient power" into traditional Ocean Energy legislation such that federal and state funding can become available to support required follow-on research and commercial development.

2. In addition to inclusion of the term "salinity gradient power" into traditional Ocean Energy legislation, it should also be included into traditional Waste Energy Recovery legislation such that federal and state funding can become available to support required follow-on research and commercial development.

3. Related membrane applied research and development of different BPM compositions and configurations and packaging configurations required for the candidate focus use.

4. Identification of a suitable size scale and application uses, for example, low-power energy harvesting wireless solutions for rapid environmental assessment or high brine storage recovery.

5. The co-development of suitable energy storage devices, optimized for the unique BPM electrical characteristics and power transfer needs required for the candidate focus use. 
ACKNOWLEDGMENTS: I would like to thank the technical reviewers and coauthors of this articles for their valuable suggestions and participation. Many thanks, as well, to Dr. Wilfrido Moreno and all my Ph.D. committee members; to Professors Luis García-Rubio, College of Marine Science (CMS), and Alberto A. Saguiés, Corrosion Engineering Laboratory, for their guidance, encouragement, and generous use of lab space and equipment; to the skilled craftsmen at the CMS machine shop-Guy Grant and Jim Mulhollan; and to Dr. Robert Carnahan, whose exposure to desalination science both ignited and fueled my interest in this exciting technology. Dr. Merz is president and founder of Dialytics, Inc. (www.dialytics.com); all other authors declare no conflicts of interest.

\section{REFERENCES}

1. Applegate, L. E. Membrane separation processes. J. Chem. Eng. 91:64-89; 1984.

2. Bard, A. J.; Faulkner, L. R. Electrochemical methodsFundamentals and applications. New York: Wiley and Sons; 2001.

3. Bond, R.; Owen, C.; Teegarden, R.; Browning, K.; Davis, T. A.; Veerapaneni, V. Zero liquid discharge desalination using a new electrodialysis technology. In: 2010 AWWA Water Quality Technology Conference \& Exposition. Savannah International Trade \& Convention Center, Savannah, GA, November 14-18; 2010.

4. Car, A.; Peinemann, K. V. Salinity power: Clean energy of the future. XXVI EMS Summer School 2009 Poster. GKSS Research Centre Geesthacht GmbH, Max-PlanckStr. 1, 21502 Geesthacht, Germany; 2009.

5. Constans, J. Marine sources of energy. New York: Pergamon Press; 1979.

6. Energy Information Administration (EIA)/United States Department of Energy. International Energy Outlook 2011. DOE/EIA-0484(2011). Washington, DC: U.S. Energy Information Administration; 2011.

7. Forgacs, C.; O'Brien, R. Utilization of membrane processes in the development of non-conventional renewable energy sources. Chem. Canada 31(5):19-21; 1979.

8. Forgacs, C. Recent developments in the utilization of salinity power. Desalination 40(1-2):191-195; 1982.

9. Gabrielli, C. Use and application of electrochemical impedance techniques. Technical Report Number 24, Solartron Analytical, Cedex, France; 1997.

10. Gerstandt, K.; Peineman, K.-V.; Skilhagen, S. E.; Thorsen, T.; Holt, T. Membrane processes in energy supply for an osmotic power plant. Desalination 224(1-3): 64-70; 2008.

11. Hays, D. W. J.; Kipps, J. L. Salt-gradient solar ponds from concentrated subsurface agricultural drainage waters of the San Joaquin Valley, California. Desalination 88(1-3): 301-309; 1992.

12. Helfferich, F. Ion exchange. New York: McGraw-Hill; 1962.

13. International Energy Agency (IEA). Renewable energy: RD\&D priorities, chapter 3, ocean energy systems. Retrieved October 2011, from www.iea.org

14. Jagur-Grodzinski, J.; Kramer, R. Novel process for direct conversion of free energy of mixing into electrical power. Ind. Eng. Chem. Process Des. Dev. 25(2):443-449; 1986.

15. Jellinek, H. H. G. Osmosis process for producing energy; U.S. Patent 3,978,344; 1976.

16. Jellinek, H. H. G.; Musuda, H. Osmo-power: Theory and performance of an osmo-power pilot plant. Ocean Eng. 8(2):103-128; 1981.

17. Jones, A. T.; Finley, W. Recent development in salinity gradient power. OCEANS 2003 Proc. 4:2284-2287; 2003.

18. Kemperman, A. J. B. Handbook on BPM technology. Enschede, The Netherlands: Twente University Press; 2000.

19. Kobatake, Y.; Takeguchi, N.; Toyoshima, Y.; Fujita, H. J. Studies of membrane phenomena. I. Membrane potential. J. Phys. Chem. 69(11):3981-3988; 1965.

20. Kudela, V.; Richau, K.; Bleha, M.; Paul, D. Orientation effects on bi-polar and other asymmetric membranes as observed by concentration potentials. Sep. Purif. Technol. 22-23:655-662; 2001.

21. Lacey, R. E. Energy by reverse electrodialysis. Ocean Eng. 7(1):1-47; 1980.

22. Lakshminarayanaiah, N. Transport phenomena in membranes. New York: Academic Press; 1969.

23. Larminie, J.; Dicks, A. Fuel cell systems explained. London: Wiley and Sons, Ltd; 2000.

24. Levenspiel, O.; de Vevers, N. The osmotic pump. Science 183(4121):157-160; 1974.

25. Libes, S. M. An introduction to marine biogeochemistry. New York: John Wiley \& Sons; 1992.

26. Loeb, S. Method and apparatus for generating power utilizing pressure-retarded osmosis; U.S. Patent, 3,906,250; 1975.

27. Loeb, S.; Norman, R. M. Osmotic power plants. Science 189(4203):654-655; 1975.

28. Manecke, G. Z. Membranakkumulator. J. Phys. Chem. 201:1-15; 1952.

29. Mani, K. N.; Electrodialysis water splitting technology. J. Membr. Sci. 58(2):117-138; 1991.

30. Merz, C. R. Investigation and evaluation of a BPM based seawater concentration cell and its suitability as a low power energy source for energy Harvesting/MEMS devices. Ph.D. dissertation, University of South Florida, Copyright; 2008.

31. Merz, C. R. Dialytic power generator using diffusion gradients; U.S. Patent 7,736,791; 2010.

32. Meyer, K. H.; Sievers, J. F. The permeability of membranes. Helv. Chim. Acta 19:649; 1936.

33. Mulder, M. Basic principles of membrane technology. Dordrecht, The Netherlands: Kluwer Academic Publishers; 2003. 
34. Murphy, G. W. Osmionic demineralization. Ind. Eng. Chem. 50:1181-1188; 1958.

35. Norman, R. W. Water salination: A source of energy. Science 186(4161):350-352; 1974.

36. O'Brien, R. N. O.; Visaisouk, S.; Turnham, B. D. Electric power from salinity gradients by reverse electrodialysis. In: Energy developments: New forms, renewables, conservation, Proc. of ENERGEX '84. New York: Pergamon Press; 1984:143-146.

37. O'Brien, R. N. Reverse electrodialysis: An unused power source. Chem. Britain 22:927-929; 1986.

38. Ohya, H. Dialytic battery convertible free energy of mixing of seawater and river water. In: Proceedings from the 3rd pacific chemical engineering congress, Seoul, Korea, May 8-11; 1983:451-456.

39. Olsson, M. S.; Wick, G.; Isaacs, J. D. Salinity gradient power: Utilizing vapor pressure differences. Science 206: 452-454; 1979.

40. Pattle, R. E. British patent application 1939/53; 1953.

41. Pattle, R. E. Production of electric power by mixing fresh and salt water in the hydroelectric pile. Nature (4431)174: 660-661; 1954.

42. Peinemann, K.-V.; Gerstandt, K.; Skilhagen, S. E.; Thorsen, T.; Holt, T. Membranes for power generation by pressure retarded osmosis. In: Peinemann, K-V.; Nunes, S. P., eds. Membranes for energy conversion. Verlag: Wiley-VCH; 2008:263-273.

43. Post, J. W.; Veerman, J.; Hamelers, V. M.; Euverink, G. J. W.; Metz, S. J.; Nymeijer, K.; Buisman, C. J. N. Salinitygradient power: Evaluation of pressure-retarded osmosis and reverse electrodialysis. J. Membr. Sci. 288:218-230; 2007.

44. Pretz, J.; Staude, E. Reverse electrodialysis (RED) with BPMs, an energy storage system. Berichte der Bunsenges. Phys. Chem. 102(4):676-685: 1998.

45. REDStack RED Update. Innovation@ @ork November 2011. Retrieved March 2012, from http://www.nwp.nl/ _docs/Innovatieprogramma_Watertechnologie/PIBoktober ENGELS.pdf
46. Scatchard, G. Ion exchanger electrodes. J. Am. Chem. Soc. 75:2883-2887; 1953.

47. Scott, K. Handbook of industrial membranes. Oxford, UK: Elsevier Advanced Technology; 1995.

48. Skråmestø, O. S.; Skilhagen, S. E.; Nielsen, W. K. Power production based on osmotic pressure. Statkraft presentation at Waterpower XVI, Spokane, WA; 2009.

49. Statkraft, June 20, 2011. Retrieved October 2011, from http://www.statkraft.com/presscentre/press_releases/stat kraft_and_Nitto_Deneko_Hydranautics.aspx.

50. Strathmann, H.; Krol, J. J.; Rapp, H. J.; Eigenberger, G. Limiting current density and water dissociation in bipolar membranes. J. Memb. Sci. 125(1):123-142; 1997.

51. Suendo, V.; Eto, R.; Osaki, T.; Higa, M.; Tanioka, A. Ionic environmental effect on the time-dependent characteristics of membrane potential in a BPM. J. Colloid Interface Sci. 240:162-171; 2001.

52. Teorell, T. An attempt to formulate a quantitative theory of membrane permeability. Proc. Soc. Exp. Biol. 33:282$285 ; 1935$.

53. University of California, Berkley Wireless Center. Retrieved October 2011, from http://bwrc.eecs.berkeley.edu/

54. Weinstein, J. N.; Leitz, F. B. Electric power from differences in salinity: The dialytic battery. Science 191(4227): 557-559; 1976.

55. Wick, G. L.; Isaacs, J. D. Utilization of the energy from salinity gradients. Wave and Salinity Gradient Energy Conversion Workshop Proceedings, University of Delaware, May 24-26; 1976:A1-34.

56. Wick, G. L.; Schmitt, W. R. Prospects for renewable energy from the sea. Mar. Technol. Soc. J. 11(5-6):16$21 ; 1977$.

57. Wick, G. L.; Isaacs, J. D. Salt domes: Is there more energy from the salt than from the oil? Science 199:1436-1437; 1978.

58. Wick, G. L. Power from salinity gradients. Energy 3:95$100 ; 1978$ 
IP: 131.247.113.220 On: Fri, 06 Sep 2019 18:00:26 Delivered by Ingenta

Article(s) and/or figure(s) cannot be used for resale. Please use proper citation format when citing this article including the DOI, publisher reference, volume number and page location. 